\title{
The engagement of young people in their own advance care planning process: a systematic narrative synthesis
}

Ben Hughes, Professor Mary R. O’Brien, Dr Anita Flynn, Dr Katherine Knighting

All members of the research team are from Edge Hill University

Corresponding author:

Ben Hughes

Faculty of Health and Social Care

Edge Hill University

St Helens Road

Ormskirk

Lancashire

L39 4QP

Tel: 01695654354

Email: Ben.Hughes@edgehill.ac.uk

Running title: Engagement of young people in advance care plans

Word count: 5,352 


\begin{abstract}
Background:

An increasing number of young people are living with life-limiting conditions. Current research about advance care planning for young people indicates differing experiences for those involved. Understanding how far young people are engaged in their own advance care plan is important to shape future practice and facilitate young people's wishes.
\end{abstract}

\title{
Aim:
}

To identify and assess the current evidence to determine the barriers and facilitators to the engagement of young people in their own advance care planning process.

\section{Design:}

A systematic narrative synthesis according to the Preferred Reporting Items for Systematic Reviews and Meta-Analyses guidelines. Study quality was assessed using a quality assessment framework ${ }^{1}$ previously used in similar research.

\section{Data sources:}

CINAHL Complete, MEDLINE, PubMed, and PsycINFO were searched for articles published between $1^{\text {st }}$ January 1990 and $31^{\text {st }}$ October 2017 . Grey literature was searched using Google Scholar and Open Grey. 
Results:

Most studies related to the engagement of young people were conducted in hospitals or other institutions. Research reported the aim to include young people in their own advance care planning, but also potential barriers to engagement. Barriers include poor communication, conflict within relationships of those in the planning process, and patchy education and training for healthcare professionals. Some existing studies are characterised by a lack of rigorous, high quality, research, limiting their impact.

\section{Conclusion:}

Irrespective of setting, engagement of young people would benefit their advance care planning. More detailed, high-quality research is needed to understand the extent of the barriers to young people's engagement in their own advance care plan and how to facilitate their involvement.

\section{Keywords}

Advance care planning, systematic narrative synthesis, adolescent, young people, young adult, patient participation

\section{Key statements}

What is already known about the topic?

- There are varying experiences for young people engaged in advance care planning

- It is unclear how far young people are engaged in their own advance care planning process 


\section{What this paper adds}

- This study demonstrates that the aim is to often include young people in their own advance care planning process

- Engaging young people in their own advance care planning process would benefit the standard of care they receive

- Communication, relationships, and the availability and access to training for healthcare professionals, can act as either a barrier or a facilitator to the engagement of young people in their advance care plan.

\section{Implications for practice, theory or policy}

- The alignment of policy and practice can both facilitate young people's engagement, and empower them, in their own advance care planning.

- A collaborative approach to advance care planning would help facilitate the engagement of young people in the process.

\section{Introduction}

\section{The development of advance care planning}

From the late 1990s, the Gold Standards Framework (GSF) ${ }^{2}$ has supported a systematic, whole systems, evidence-based approach to improving end-of-life care (EoLC) for all patients. ${ }^{2,3}$ Advance care planning (ACP) is one element within the GSF which aims to nurture communication and develop a consistent approach between practitioners ${ }^{4}$ by using a formal process to provide high quality EoLC. Advance care plans (ACPs) perform several functions, ${ }^{5}$ such as: the opportunity to consider aspects of loss of self at the end-of-life; to acknowledge the prospect of death and negotiate personal preferences around future treatment; to make clear personal preferences 
around clinical interventions and personal possessions in the event that capacity for decision-making is lost; and discuss the delegation of future care in the event that capacity is lost.

ACP has been practised for a number of years in the United States, Canada and Australia and is based on the preservation of personal autonomy in decision-making. ${ }^{6}$ As an example of patient participation, ACP encourages patients to be involved in their own care. ${ }^{7}$ The United Kingdom's first End of Life Care Strategy set out the use of ACP for adults. ${ }^{8}$ The resulting Liverpool Care Pathway (LCP) became the standard and most widely-used version of ACP. However, due to a number of high profile cases and media reports between 2009 to $2012,{ }^{9}$ it was finally phased out in 2014 .

\section{Advance care planning for young people}

There is a misconception that ACP is solely used for terminally ill elderly people. ${ }^{10,11}$ Yet an increasing number of young people with complex, life-limiting conditions (LLCs) could benefit from its use. ${ }^{12}$ Over 49,000 young people in the UK currently have a LLC or Life-Threatening Condition (LTC). ${ }^{13}$ Furthermore, $70 \%$ of young people's deaths in England are complicated by problematic LLCs. ${ }^{12}$ An understanding of the experiences and level of engagement of this population in their own care planning is important to delivering palliative care.

For this review, young people are those aged 13-24 years. This term corresponds with the definition of a 'young adult' as given by Medical Subject Headings (MeSH) (US National Library of Medicine 2017). This definition also standardises existing age ranges used by children's hospices in the UK. 
The lack of a clear and consistent definition of ACP makes it both difficult to identify within the literature and hard to translate theory into practice. ${ }^{14}$ Adult ACP focuses on recognising and communicating values, life goals and preferences with specific regard to future medical care. ${ }^{15}$ However, advance care planning for young people (ACPfYP) simply records advance wishes of the young person and/or their parent/carer. ${ }^{16,17}$ This definition has been developed to include actions that should be taken when the young person's condition becomes unstable, deteriorates or they develop potentially lifethreatening complications of their illness. ${ }^{18}$

ACPfYP was developed from 2010 to help young people and their parents/carers communicate their wishes, as well as helping with the grieving process and support around the death of the young person. ${ }^{19}$ However, palliative care resources are focused more on provision for adults than provision for young people. ${ }^{20}$ Consequently, most research currently focuses on ACP for adults and there is limited research into the engagement of young people in their own ACP.

The implementation of ACPfYP during palliative care is a key contributor to the success of effective communication. ${ }^{21}$ This, in turn, can help determine high quality care. ${ }^{22}$ Research suggests there are varying experiences for those using ACPfYP due to the complex needs of young people, misunderstanding of healthcare professionals (HCPs) around how and when to implement them ${ }^{23}$ and failure to keep parents/carers informed of the process of ACPfYP. ${ }^{24}$ Additionally, as with adult ACP, there is no single standard national documentation used for young people. ${ }^{25}$ As a result, it is currently unclear how far young people engage in their own ACP. A first step towards improving 
the consistent use of ACPfYP, with the involvement of young people, is to understand the barriers and facilitators for young people's engagement in their own ACP. This review is a timely summary of existing research to benchmark current understanding of these key areas.

\section{Method}

\section{Review question}

What are the factors that may facilitate or mitigate engagement of young people in their own ACP?

To help recognise barriers and facilitators to the process of engaging young people in their own ACP, this synthesis has three key objectives to identify key stages of the process and how this impacts on the engagement of young people:

1. to explore who is involved in the advance care planning process;

2. to explore when the process is started; and

3. to explore how key participants (young person, their parents/carers and healthcare professionals) are engaged in the process and how this facilitates or mitigates engagement of the young person.

\section{Review design}

Existing evidence about young people's engagement in their ACP is diverse and includes both qualitative and quantitative studies. Therefore, an approach to help synthesise the literature was required. Narrative synthesis was the most appropriate approach to integrate these different studies because its rigourous nature is suitable 
to facilitate the synthesis of heterogeneous studies. ${ }^{26,27}$ The definition of terms used in the review is in Table 1.

Table 1 - Definition of terms

\begin{tabular}{|c|c|c|}
\hline Abbreviation & Term & Definition \\
\hline $\mathrm{ACP}$ & $\begin{array}{l}\text { Advance Care } \\
\text { Planning }\end{array}$ & $\begin{array}{l}\text { A voluntary discussion-based process } \\
\text { between an individual, their care providers and } \\
\text { those close to them, about future care where a } \\
\text { future loss of the patient's capacity is } \\
\text { anticipated. }{ }^{30}\end{array}$ \\
\hline ACPs & $\begin{array}{ll}\text { Advance } & \text { Care } \\
\text { Plans } & \end{array}$ & $\begin{array}{l}\text { The individual instance of an advance care } \\
\text { plan, which is to be distinct from the } \\
\text { overarching ACP process. }\end{array}$ \\
\hline ACPfYP & $\begin{array}{l}\text { Advance r care } \\
\text { plans for young } \\
\text { people }\end{array}$ & $\begin{array}{l}\text { An advance care plan which is implemented for } \\
\text { someone aged } 13-24 \text { years. }\end{array}$ \\
\hline EoL & End-of-life & $\begin{array}{l}\text { The period of time before death, usually } \\
\text { considered to be the last } 12 \text { months of life. }\end{array}$ \\
\hline EoLC & End-of-life Care & $\begin{array}{l}\text { Care that helps people with advanced, } \\
\text { progressive, incurable illness to live as well as } \\
\text { possible until they die. }{ }^{31}\end{array}$ \\
\hline GSF & $\begin{array}{l}\text { Gold Standards } \\
\text { Framework }\end{array}$ & $\begin{array}{l}\text { Developed from 1998, the GSF supports a } \\
\text { whole systems approach to improving end-of- } \\
\text { life care (EoLC) for all patients. }{ }^{3}\end{array}$ \\
\hline HCPs & $\begin{array}{l}\text { Healthcare } \\
\text { Professionals }\end{array}$ & $\begin{array}{l}\text { Professionals who: study, diagnose, treat and } \\
\text { prevent human illness, injury and other } \\
\text { physical and mental impairments; advise on or } \\
\text { apply preventive and curative measures, and } \\
\text { promote health; conduct research and improve } \\
\text { or develop concepts, theories and operational } \\
\text { methods to advance evidence-based health } \\
\text { care; and may also supervise other health } \\
\text { workers. }\end{array}$ \\
\hline LLCs & $\begin{array}{l}\text { Life limiting } \\
\text { conditions }\end{array}$ & $\begin{array}{l}\text { Conditions which cause progressive } \\
\text { deterioration, for which there is no reasonable } \\
\text { hope of cure and from which a child or young } \\
\text { person will die. }{ }^{22}\end{array}$ \\
\hline LCP & $\begin{array}{l}\text { Liverpool Care } \\
\text { Pathway }\end{array}$ & $\begin{array}{l}\text { An approach to care, including a complex set of } \\
\text { interventions, which aimed replicate the } \\
\text { hospice standard of case within hospitals. }{ }^{33}\end{array}$ \\
\hline LTCs & $\begin{array}{l}\text { Life-threatening } \\
\text { conditions }\end{array}$ & $\begin{array}{l}\text { Conditions in which curative treatment may be } \\
\text { feasible but can fail. }{ }^{33}\end{array}$ \\
\hline
\end{tabular}




\begin{tabular}{|l|l|l|}
\hline- & Palliative Care & $\begin{array}{l}\text { An active and total approach to care, from the } \\
\text { point of diagnosis or recognition, which } \\
\text { continues through to death and beyond. }{ }^{31}\end{array}$ \\
\hline- & Parallel Planning & $\begin{array}{l}\text { Plans are made for life, while also allowing for } \\
\text { a deterioration in condition, or even death. }{ }^{31}\end{array}$ \\
\hline- & Young Person & Someone aged 13-24 years. ${ }^{34}$ \\
\hline
\end{tabular}

\section{Search strategy}

\section{Database searches}

The databases of Cumulative Index to Nursing and Allied Health Literature (CINAHL Complete), MEDLINE (Medical Literature Analysis and Retrieval System Online), PubMed, (Public Medline) and PsycINFO (Psychological Information Database) were searched for articles published from $1^{\text {st }}$ January 1990 to $31^{\text {st }}$ October 2017 . Grey literature was searched using Google Scholar and Open Grey. Citation searching and reference list checking was performed on all identified papers.

Searches included all existing literature and grey literature to present a broad and balanced reflection of the involvement of young people in their ACP. Therefore, the review included both qualitative and quantitative studies and incorporates all study types identified, including systematic reviews, cohort studies, case studies, interviews, randomised control studies and retrospective studies.

\section{Database search terms}

Medical subject headings $(\mathrm{MeSH})$, or a thesaurus, were employed to conduct the search, where possible (see Table 2). The Preferred Reporting Items for Systematic Reviews and Meta-Analysis (PRISMA) ${ }^{35,36}$ guidelines were followed for this review, as in similar reviews ${ }^{27}$. 


1. Advance care plan $\begin{aligned} & * \\ & \text { document OR wishes OR My Choices }\end{aligned}$
AND
2. Paed $^{*}$ OR Child ${ }^{*}$ OR Young person OR Adoles $\left.{ }^{*}\right]$
3. End of life OR Palliative

\section{Selection criteria}

Studies were selected for review based on clear inclusion and exclusion criteria (see Table 3).

Table 3 - Inclusion and exclusion criteria for study selection

\begin{tabular}{|c|c|}
\hline Inclusion criteria & Exclusion criteria \\
\hline $\begin{array}{l}\text { - Sources written in English. } \\
\text { - Studies conducted at any location } \\
\text { or place of care. } \\
\text { - Studies including evidence about } \\
\text { the engagement of young people } \\
\text { (aged } 13-24 \text { ) in their own advance } \\
\text { care planning. } \\
\text { - Sources published between } 1^{\text {st }} \\
\text { January } 1990 \text { and } 31^{\text {st }} \text { October } \\
2017 \text {. }\end{array}$ & $\begin{array}{l}\text { - Sources published before } 1990 . \\
\text { - Sources written in languages } \\
\text { other than English. } \\
\text { - Studies focused on advance care } \\
\text { planning for adults (aged over } 24 \\
\text { years) and children (aged under } \\
13 \text { years). }\end{array}$ \\
\hline
\end{tabular}




\section{Data extraction and method of synthesis}

The search strategy was adopted from similar previous research ${ }^{27}$ and adheres to the following narrative synthesis guidelines recommended by Popay et al. ${ }^{37}$

1. The first stage was to conduct a preliminary analysis of the literature to identify relevant sources. This was a two-step approach to identify and then screen the literature:

i. Searches were conducted using the databases identified above to locate abstracts and, where possible, titles of studies containing the search terms. This generated a list of potential studies to include in the synthesis. Results were then screened to remove duplicates and ensure that relevant studies were included in the synthesis. $\mathrm{BH}$ read and assessed the remaining studies for eligibility. This process allowed a further selection and exclusion of studies to take place. Studies which did not meet the inclusion criteria set out above were removed.

ii. The title and abstract of remaining studies were then screened and studies not meeting the criteria were excluded. The full text of the remaining 25 articles was assessed for eligibility by $\mathrm{BH}$. Over $50 \%$ $(n=15)$ of these papers were shared within the research team (MoB, $A F, K K)$ for independent eligibility assessment and to increase the rigour of the study. Disagreements about study inclusion at each stage of study selection were resolved through discussion within the team. 
2. The second stage was to explore the relationships between the results from the studies. Data from the studies were extracted and presented in a Characteristics of Included Studies table, before being thematically analysed by $\mathrm{BH}$ and discussed within the research team. This process ensured consistency, clarity and transparency within the data extraction and management process. The selected characteristics were based on those identified in previous research into ACP. ${ }^{38}$ The table included the following information about each publication: study details; aims and objectives; study design; participant characteristics; country; setting; key findings; theme(s); included/excluded and quality assessment score.

3. Assessment of the robustness of the synthesis was carried out by the research team at each step of the process. A narrative synthesis approach was used to present themes found as it is well-suited to synthesising evidence from studies that are heterogeneous in method. ${ }^{37}$

The review has been registered with PROSPERO (PROSPERO registration number: CRD42017079823).

A total of 22 articles met the inclusion criteria and were included in the synthesis (see Figure 1 - PRISMA flow diagram). 
Figure 1 - PRISMA flow diagram
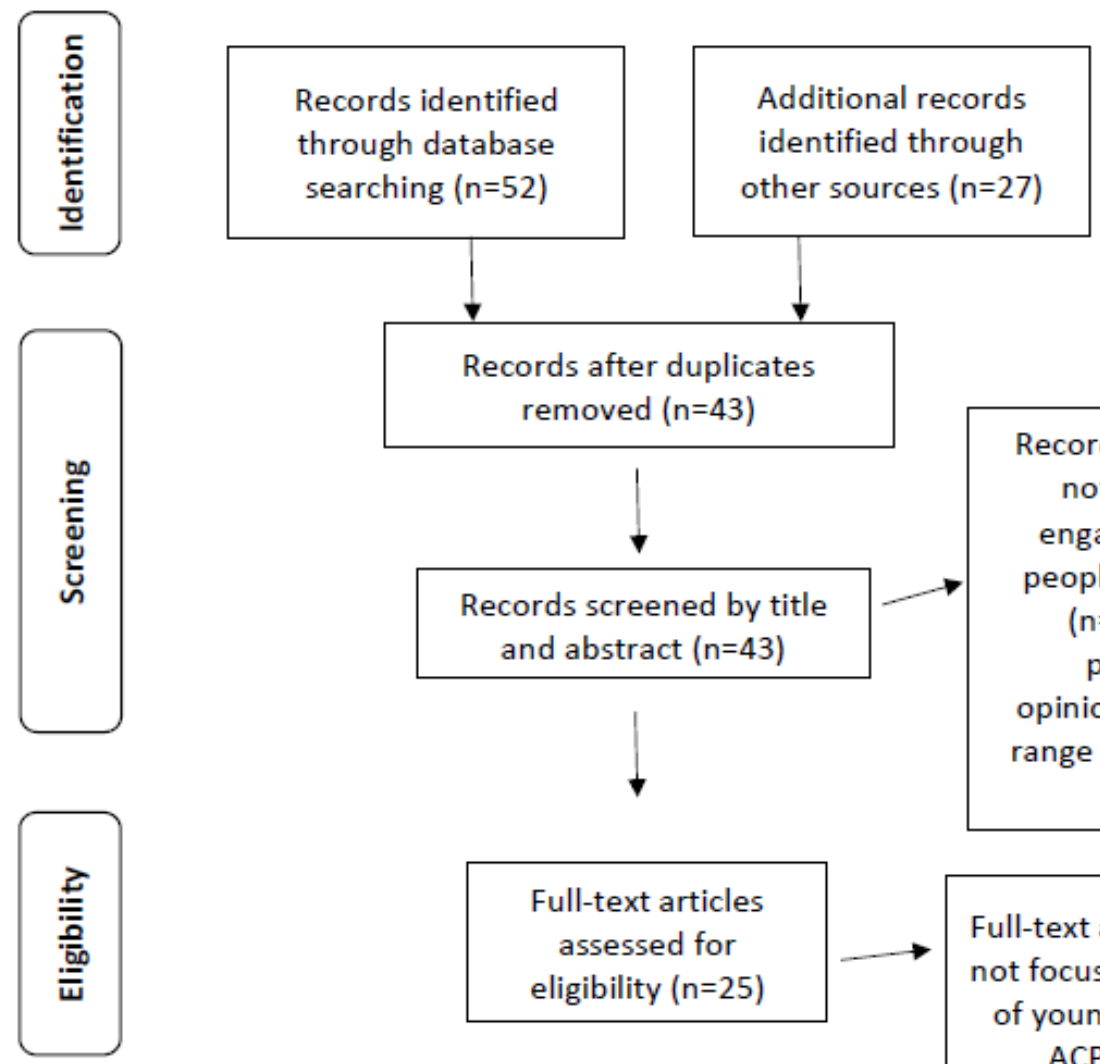

Records excluded ( $n=18)$ : not focused on the engagement of young people in their own ACP ( $n=10)$; discussion paper/personal opinion/policy ( $n=7)$; age range outside $13-24$ years $(n=1)$
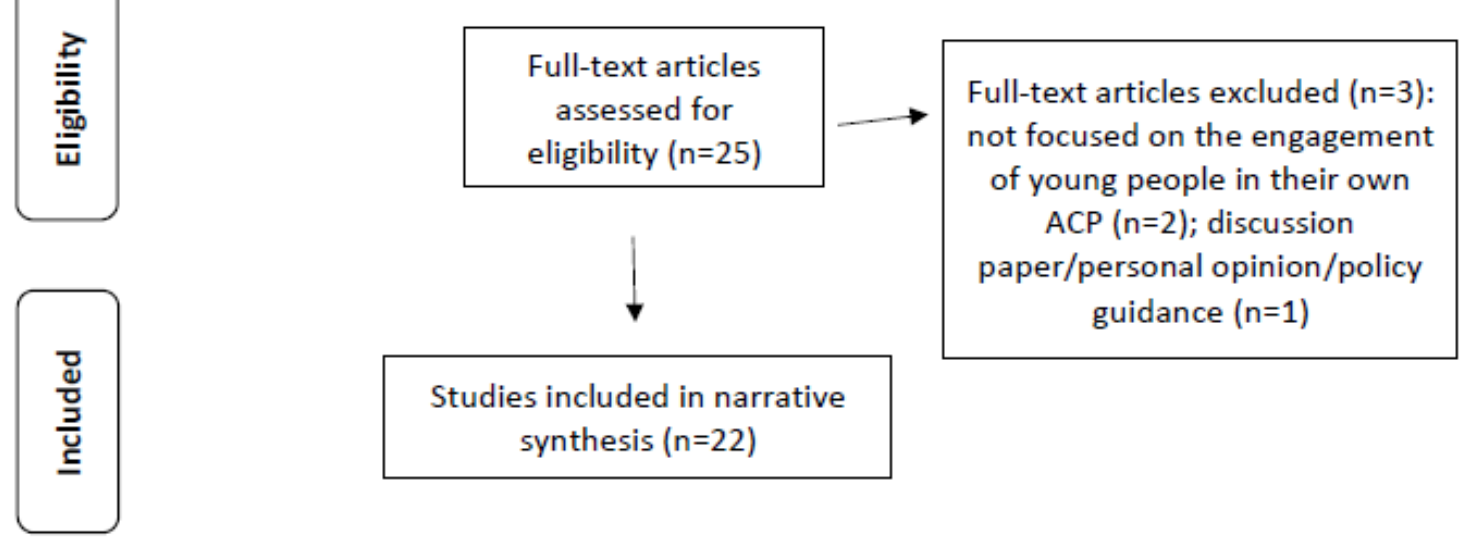

\section{Assessment of quality}

Hawker et al.'s ${ }^{1}$ assessment framework (Appendix 1) and scoring system (Appendix 2) were utilised to assess the quality of the studies included in the synthesis. This approach mirrors that taken in previous similar studies where either palliative care research was undertaken, a systematic narrative synthesis was conducted, or a combination of the two was presented. ${ }^{27}$ The assessment framework allows literature to be scored (9 very poor; 36 very good) to indicate the methodological rigour of each study. ${ }^{1}$ This scoring process gives a clear indication of the strengths and weaknesses 
of each study and so provides clarity, transparency and rigour in the quality assessment process. $^{1}$

\section{Overview of the studies}

Publication dates of the studies ranged from 2004 to 2017. Studies were heterogeneous, with the majority being quantitative $(n=15)^{24,39-51}$; three were qualitative method ${ }^{52-54}$ and the remaining studies $(n=4)^{53,55-57}$ used a mixed methods approach. The 22 studies included were primarily from the United States (US) $(n=14),{ }^{40,42-44,47-50,52,56-58}$ with further studies coming from the United Kingdom $(\mathrm{n}=4), 24,39,54,55$ France, ${ }^{41}$ Germany, ${ }^{59}$ Japan. ${ }^{51}$ The remaining study, a systematic review, included research from the US and Australia. ${ }^{46}$

Study settings included: children's services/hospitals/clinics/medical centres $(n=11) ; 39-$ 42,44,45,48,49,52,54,55 cancer centres/institutes $(n=2) ; 50,58$ and universities $(n=2) .43,57$ Other research was conducted within National Health Service (NHS) Trusts; ${ }^{24}$ via a national board of haematologists; ${ }^{51}$; and a range of settings: care settings only, ${ }^{48,59}$ a combination of care and non-care settings; ${ }^{* 6}$ paediatric hospitals and HIV clinics; ${ }^{47}$ and a cancer institute and a university. ${ }^{53}$

Participants varied in their diagnosis: cancer and/or HIVIAIDS $(n=9)^{40,44,47-49,51,53,58}$ LLCs or LTCs $(n=6) ; 24,39,41,42,46,54$ chronic/severe/serious illness $(n=3) ; 50,56,59$ and cystic fibrosis $(n=1) .{ }^{52}$ No specific condition was diagnosed in the young people in the remaining studies $(n=3) .43,55,57$ 
Similarly, young people's knowledge of their diagnosis varied between studies: it was not mentioned in half of the studies $(n=11) ; 24,39,41,42,44,46,47,53-55,59$ young people were aware of their diagnosis in a third of the studies $(n=7) ; 40,48-50,52,58$ in a small number of studies $(n=2),{ }^{51,56}$ at least some participants were aware of their diagnosis, while others were unaware; and the young people did not have a diagnosed condition in the remaining studies $(n=2) .43,57$

All participants were English-speaking and, where race/ethnicity was acknowledged, they identified across a range: Black, African-American, Hispanic/Latino, Asian, Black, White/Caucasian, American Indian/Alaskan, Biracial, Asian/Pacific Islander. Educational attainment and income level was mixed across those studies in which these factors were identified. $40,43,44,47-49,57$ The male/female split between young people was fairly equal in most studies.

\section{Themes}

Analysis produced four themes: how ACP works in practice; communication; training and education; and relationships; presented in the narrative below. The 22 studies are summarised in Table 3. 
Table 3 - Data extraction and study quality

Characteristics of Included Studies Table

\begin{tabular}{|c|c|c|c|c|c|c|c|c|}
\hline Study details & $\begin{array}{l}\text { Aims and } \\
\text { objectives }\end{array}$ & Study design & $\begin{array}{c}\text { Participant } \\
\text { characteristics }\end{array}$ & Country & Setting & Key findings & $\begin{array}{l}\text { Theme(s) of included } \\
\text { papers }\end{array}$ & $\begin{array}{l}\text { Included/excluded } \\
\text { (Assessment } \\
\text { Framework score for } \\
\text { included studies) }\end{array}$ \\
\hline $\begin{array}{l}\text { Keeping all } \\
\text { options open: } \\
\text { Parents' } \\
\text { approaches to } \\
\text { advance care } \\
\text { planning }\end{array}$ & $\begin{array}{l}\text { To investigate } \\
\text { how parents of } \\
\text { children and } \\
\text { young people with } \\
\text { LLCs approach } \\
\text { and experience } \\
\text { ACP }\end{array}$ & $\begin{array}{l}\text { Open ended, } \\
\text { semi- } \\
\text { structured } \\
\text { interviews }\end{array}$ & $\begin{array}{l}\text { (i) Parents whose } \\
\text { child was } \\
\text { currently } \\
\text { receiving } \\
\text { services from the } \\
\text { palliative care } \\
\text { team ( } \mathrm{n}=28 \text { ) } \\
\text { (ii) Bereaved } \\
\text { parents whose } \\
\text { child had } \\
\text { received care } \\
\text { from the } \\
\text { palliative care } \\
\text { team and had } \\
\text { died } 6-10 \\
\text { months } \\
\text { previously (n=29) } \\
\\
\text { A child population } \\
\text { aged } 0 \text { - } 19 \text { years } \\
\text { with a diverse } \\
\text { range of life- } \\
\text { limiting conditions, } \\
\text { ethnic and socio- } \\
\text { economic } \\
\text { backgrounds. }\end{array}$ & UK & $\begin{array}{l}\text { Unidentified } \\
\text { specialist } \\
\text { palliative } \\
\text { care service }\end{array}$ & $\begin{array}{l}\text { Most decisions } \\
\text { were made } \\
\text { relatively late in the } \\
\text { child's illness } \\
\text { It is questionable } \\
\text { whether the parents } \\
\text { in our study would } \\
\text { have welcomed } \\
\text { earlier discussions } \\
\text { Parents need more } \\
\text { support and more } \\
\text { information about } \\
\text { the aims of ACP to } \\
\text { help make } \\
\text { decisions }\end{array}$ & $\begin{array}{ll}\text { ACP in practice } \\
\text { - } & \text { How young } \\
\text { people are } \\
\text { engaged in ACP } \\
\text { discussions } \\
\text { Relationships } \\
\text { - The dynamics in } \\
\text { relationships } \\
\text { between young } \\
\text { people and their } \\
\text { parents } \\
\text { - Highlighted the } \\
\text { importance of a } \\
\text { trusting } \\
\text { relationship in the } \\
\text { ACP process }\end{array}$ & $\begin{array}{l}\text { Included } \\
\text { The focus of the } \\
\text { study is about } \\
\text { engaging parents as } \\
\text { well as young people } \\
\text { in ACP } \\
\text { Hawker et al, } \\
\text { framework score: } \\
\text { (30/36) }\end{array}$ \\
\hline
\end{tabular}




\begin{tabular}{|c|c|c|c|c|c|c|c|c|}
\hline $\begin{array}{l}\text { Was there a } \\
\text { plan? End-of-life } \\
\text { care for children } \\
\text { with life-limiting } \\
\text { conditions: a } \\
\text { review of multi- } \\
\text { service } \\
\text { healthcare } \\
\text { records } \\
60\end{array}$ & $\begin{array}{l}\text { To compare } \\
\text { documented EoL } \\
\text { planning with } \\
\text { published } \\
\text { children's } \\
\text { palliative care } \\
\text { standards, across } \\
\text { a range of } \\
\text { children's } \\
\text { healthcare } \\
\text { services and to } \\
\text { assess the impact } \\
\text { on practice of } \\
\text { written guidelines } \\
\text { to support EoL } \\
\text { care planning }\end{array}$ & $\begin{array}{l}\text { A manual } \\
\text { retrospective } \\
\text { review of } \\
\text { healthcare } \\
\text { records }\end{array}$ & $\begin{array}{l}\text { Children with a } \\
\text { diagnosed LLC or } \\
\text { LTC, who had died } \\
\text { before the age of } \\
18 \text { years, between } \\
\text { October } 2008 \text { and } \\
\text { March } 2010, \text { within } \\
\text { a defined } \\
\text { geographical area } \\
\text { served by one or } \\
\text { more of the } \\
\text { participating } \\
\text { services } \\
\text { (n=114 records } \\
\text { relating to } 48 \\
\text { children; } 24 \text { boys } \\
\text { and } 24 \text { girls) } \\
\text { A range of LLCs }\end{array}$ & UK & $\begin{array}{l}\text { Unspecified } \\
\text { services in } \\
\text { the West of } \\
\text { England }\end{array}$ & $\begin{array}{l}\text { Documented EoL } \\
\text { planning varies } \\
\text { between services } \\
\text { Professionals can } \\
\text { help prepare staff } \\
\text { to engage families } \\
\text { in these } \\
\text { conversations }\end{array}$ & 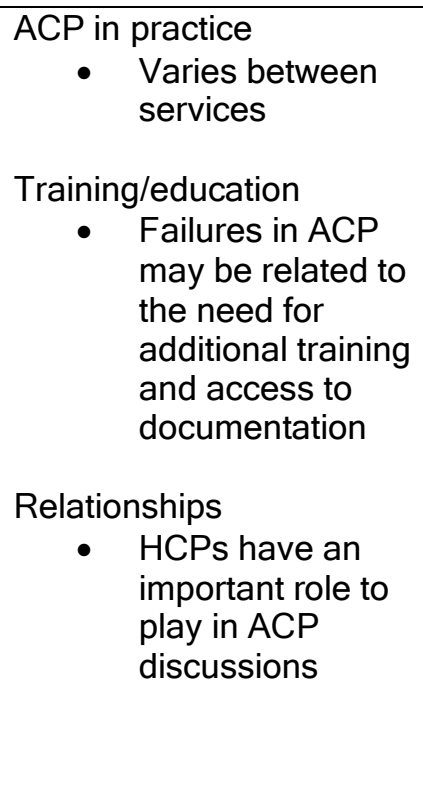 & $\begin{array}{l}\text { Included } \\
\text { The focus of the } \\
\text { study is about } \\
\text { engaging young } \\
\text { people in the ACP } \\
\text { process } \\
\text { Hawker et al, } \\
\text { framework score: } \\
(27 / 30)\end{array}$ \\
\hline $\begin{array}{l}\text { Service } \\
\text { evaluation of an } \\
\text { advance care } \\
\text { plan tool }^{55}\end{array}$ & $\begin{array}{l}\text { Investigate how } \\
\text { accurately the } \\
\text { documentation } \\
\text { was being } \\
\text { completed } \\
\text { Ascertain the } \\
\text { appropriateness } \\
\text { of the tool from } \\
\text { the family and } \\
\text { staff perspective } \\
\text { Discover the } \\
\text { extent to which } \\
\text { families were able } \\
\text { to agree care at } \\
\text { the end of life, }\end{array}$ & $\begin{array}{l}\text { Mixed } \\
\text { methods }\end{array}$ & $\begin{array}{l}\text { ACP document } \\
\text { analysis from } 3 \\
\text { research sites } \\
\text { Parents }(n=4) \text { from } \\
2 \text { research sites } \\
\text { Focus groups with } \\
\text { unspecified } \\
\text { professionals and } \\
\text { lead nurses ( } n=17 \text { ) } \\
\text { No information } \\
\text { about the } \\
\text { breakdown of } \\
\text { gender, ethnicity or }\end{array}$ & UK & $\begin{array}{l}\text { Children's } \\
\text { services in } \\
\text { East Kent }\end{array}$ & $\begin{array}{l}\text { Inconsistent } \\
\text { structure and } \\
\text { formatting of ACP } \\
\text { documentation, } \\
\text { leading to } \\
\text { ambiguity in their } \\
\text { use } \\
\text { HCP knowledge of } \\
\text { the young people } \\
\text { and the ACP } \\
\text { process is } \\
\text { important } \\
\text { There needs to be } \\
\text { a state of } \\
\text { awareness and }\end{array}$ & $\begin{array}{ll}\text { ACP in practice } \\
\text { - } \\
\text { Issues around the } \\
\text { format of } \\
\text { documentation } \\
\text { - } \quad \text { Timing of ACP } \\
\text { needs to be } \\
\text { considered } \\
\text { - } \quad \text { Young people } \\
\text { should be } \\
\text { involved in ACP } \\
\text { discussions } \\
\text { Communication } \\
\text { Barriers to } \\
\text { families wanting } \\
\text { to engage }\end{array}$ & $\begin{array}{l}\text { Included } \\
\text { Focus is on } \\
\text { engagement of } \\
\text { families rather than } \\
\text { the engagement of } \\
\text { young people } \\
\text { Hawker et al, } \\
\text { framework score: } \\
(32 / 36)\end{array}$ \\
\hline
\end{tabular}




\begin{tabular}{|c|c|c|c|c|c|c|c|c|}
\hline & $\begin{array}{l}\text { including } \\
\text { resuscitation } \\
\text { decisions } \\
\text { Identify staff } \\
\text { perceptions of } \\
\text { training received } \\
\text { regarding } \\
\text { application of the } \\
\text { tool } \\
\text { Identify and build } \\
\text { on the strengths, } \\
\text { and make } \\
\text { recommendation } \\
\text { for improvement }\end{array}$ & & $\begin{array}{l}\text { socio-economic } \\
\text { groups }\end{array}$ & & & $\begin{array}{l}\text { readiness for the } \\
\text { ACP process to } \\
\text { engage parents } \\
\text { ACPs may be } \\
\text { inappropriate in } \\
\text { some } \\
\text { circumstances e.g. } \\
\text { conflict with } \\
\text { religious beliefs } \\
\text { ACP can be } \\
\text { positive if used } \\
\text { proactively, is } \\
\text { family-driven and is } \\
\text { introduced in the } \\
\text { home environment } \\
\text { Timing of ACP is } \\
\text { important e.g. not } \\
\text { when the young } \\
\text { person's condition } \\
\text { is unstable }\end{array}$ & $\begin{array}{cl}\text { Training/education } \\
\text { - } & \text { Current training } \\
& \text { not always } \\
& \text { consistent } \\
& \\
\text { Relationships } \\
\text { - } & \text { Some tension in } \\
& \text { relationships }\end{array}$ & \\
\hline $\begin{array}{l}\text { Including the } \\
\text { Perspective of } \\
\text { the Adolescent } \\
\text { in Palliative } \\
\text { Care } \\
\text { Preferences } 52\end{array}$ & $\begin{array}{l}\text { To present issues } \\
\text { and challenges } \\
\text { that HCPs } \\
\text { encounter and to } \\
\text { describe how } \\
\text { communication } \\
\text { can be facilitated } \\
\text { between the } \\
\text { patient, family and } \\
\text { HCPs }\end{array}$ & Case study & $\begin{array}{l}\text { The case is an 18- } \\
\text { year-old woman } \\
\text { diagnosed with } \\
\text { cystic fibrosis as an } \\
\text { infant. Her disease } \\
\text { progression has } \\
\text { resulted in more } \\
\text { frequent and longer } \\
\text { hospitalisations }\end{array}$ & US & $\begin{array}{l}\text { Children's } \\
\text { Mercy } \\
\text { Hospitals } \\
\text { and Clinics in } \\
\text { Kansas City, } \\
\text { Missouri }\end{array}$ & $\begin{array}{l}\text { Communication } \\
\text { tools: } \\
\text { - can facilitate } \\
\text { young } \\
\text { people's } \\
\text { perceptions, } \\
\text { beliefs, } \\
\text { values, } \\
\text { preferences } \\
\text { and goals, as } \\
\text { well the } \\
\text { success of } \\
\text { available } \\
\text { coping } \\
\text { mechanism } \\
\end{array}$ & $\begin{array}{l}\text { ACP in practice } \\
\text { - How ACP works } \\
\text { for the young } \\
\text { person in the } \\
\text { study } \\
\text { Communication } \\
\text { - Can help } \\
\text { understand young } \\
\text { people and the } \\
\text { care they need } \\
\text { Can help young } \\
\text { people develop } \\
\text { skills to convey } \\
\text { their own care }\end{array}$ & $\begin{array}{l}\text { Included } \\
\text { Discusses the } \\
\text { engagement of } \\
\text { young people within } \\
\text { the family context } \\
\text { Hawker et al, } \\
\text { framework score: } \\
(21 / 36)\end{array}$ \\
\hline
\end{tabular}




\begin{tabular}{|c|c|c|c|c|c|c|c|c|}
\hline & & & & & & $\begin{array}{ll}- & \text { can help } \\
\text { initiate difficult } \\
\text { conversations } \\
\text { may initiate } \\
\text { thinking about } \\
\text { personal and } \\
\text { health care } \\
\text { goals }\end{array}$ & $\begin{array}{l}\text { treatment } \\
\text { decisions }\end{array}$ & \\
\hline $\begin{array}{l}\text { Acceptability of } \\
\text { Family-Centered } \\
\text { Advanced Care } \\
\text { Planning for } \\
\text { Adolescents } \\
\text { With HIV }{ }^{40}\end{array}$ & $\begin{array}{l}\text { To determine the } \\
\text { appropriateness } \\
\text { of engaging } \\
\text { adolescents with } \\
\text { chronic or life- } \\
\text { limiting illnesses } \\
\text { in advance care } \\
\text { planning }\end{array}$ & $\begin{array}{l}\text { Randomised } \\
\text { control trial }\end{array}$ & $\begin{array}{l}\text { Young people aged } \\
\text { 14-21 years } \\
\text { Participants were } \\
\text { aware of their HIV } \\
\text { diagnosis; a } \\
\text { documented IQ } \\
\text { score <70; no } \\
\text { documented } \\
\text { diagnosis of severe } \\
\text { depression, } \\
\text { suicidal/homicidal } \\
\text { ideation or } \\
\text { psychosis; and able } \\
\text { to understand } \\
\text { English }\end{array}$ & US & $\begin{array}{l}6 \text { unspecified } \\
\text { US urban } \\
\text { hospitals with } \\
\text { high AIDS } \\
\text { rates }\end{array}$ & $\begin{array}{l}\text { Family-centred } \\
\text { ACP enabled } \\
\text { worthwhile } \\
\text { conversations, } \\
\text { while } \\
\text { simultaneously } \\
\text { eliciting intense } \\
\text { emotions } \\
\text { Evidence of the } \\
\text { feasibility, } \\
\text { acceptability, and } \\
\text { safety of ACPfYP }\end{array}$ & $\begin{array}{ll}\text { ACP in practice } \\
\text { - } & \text { Families want to } \\
& \text { hear their own } \\
& \text { child's voice } \\
\text { - } & \text { Resilience of } \\
& \text { young people in } \\
& \text { ACP discussions } \\
\text { Communication } \\
\text { - } \\
\text { FaCE enabled } \\
\text { high quality EoL } \\
\text { conversations } \\
\text { between families } \\
\text { and their teens }\end{array}$ & $\begin{array}{l}\text { Included } \\
\text { Identifies attitudes of } \\
\text { young people to ACP } \\
\text { Hawker et al, } \\
\text { framework score: } \\
(29 / 36)\end{array}$ \\
\hline $\begin{array}{l}\text { Advance care } \\
\text { planning and } \\
\text { place of death in } \\
\text { a paediatric } \\
\text { palliative care } \\
\text { unit in France }{ }^{41}\end{array}$ & $\begin{array}{l}\text { To compare two } \\
\text { periods to } \\
\text { evaluate the } \\
\text { impact of ACPs } \\
\text { Identify the } \\
\text { challenges and } \\
\text { benefits of } \\
\text { developing } \\
\text { advance care } \\
\text { plans with the }\end{array}$ & $\begin{array}{l}\text { Retrospective } \\
\text { study }\end{array}$ & $\begin{array}{l}\text { No specific } \\
\text { information } \\
\text { provided } \\
\text { The article was a } \\
\text { general discussion } \\
\text { of the experiences } \\
\text { of the authors at } \\
\text { their paediatric } \\
\text { palliative care unit }\end{array}$ & France & $\begin{array}{l}\text { Paediatric } \\
\text { palliative } \\
\text { care unit }\end{array}$ & $\begin{array}{l}\text { Advance care } \\
\text { planning is crucial } \\
\text { to involve families } \\
\text { of paediatric } \\
\text { patients in decision- } \\
\text { making and help } \\
\text { them understand } \\
\text { that they can have } \\
\text { their say in what } \\
\text { happens to their } \\
\text { child in the final } \\
\text { phase }\end{array}$ & $\begin{array}{l}\text { ACP in practice } \\
\text { - Starting ACP } \\
\text { discussions early } \\
\text { is beneficial } \\
\text { Communication } \\
\text { - ACP discussions } \\
\text { can be difficult but } \\
\text { are beneficial }\end{array}$ & $\begin{array}{l}\text { Included } \\
\text { Includes the role of } \\
\text { young people within } \\
\text { the family context in } \\
\text { the ACP process } \\
\text { Hawker et al, } \\
\text { framework score: } \\
(21 / 36)\end{array}$ \\
\hline
\end{tabular}




\begin{tabular}{|c|c|c|c|c|c|c|c|c|}
\hline & $\begin{array}{l}\text { families of } \\
\text { paediatric patients }\end{array}$ & & & & & & $\begin{array}{l}\text { - } \begin{array}{l}\text { Potential for } \\
\text { conflict }\end{array} \\
\text { con }\end{array}$ & \\
\hline $\begin{array}{l}\text { Barriers to } \\
\text { Conducting } \\
\text { Advance Care } \\
\text { Discussions for } \\
\text { Children With } \\
\text { Life-Threatening } \\
\text { Conditions }^{42}\end{array}$ & $\begin{array}{l}\text { To identify } \\
\text { barriers to } \\
\text { conducting } \\
\text { advance care } \\
\text { discussions for } \\
\text { children with } \\
\text { LTCs }\end{array}$ & Survey & $\begin{array}{l}\text { Physicians ( } \mathrm{n}=107) \\
\text { and nurses } \\
(\mathrm{n}=159) \text {. } \\
\text { Participants } \\
\text { included all ICU } \\
\text { and oncology } \\
\text { attending } \\
\text { physicians, fellows, } \\
\text { hospitalists, nurses, } \\
\text { and advance } \\
\text { practice nurses. }\end{array}$ & US & $\begin{array}{l}\text { The medical/ } \\
\text { surgical ICU, } \\
\text { medicine } \\
\text { ICU, cardiac } \\
\text { ICU (CICU), } \\
\text { and oncology } \\
\text { ward at } \\
\text { Children's } \\
\text { Hospital } \\
\text { Boston; and } \\
\text { the } \\
\text { outpatient } \\
\text { oncology } \\
\text { service at the } \\
\text { Dana-Farber } \\
\text { Cancer } \\
\text { Institute }\end{array}$ & $\begin{array}{l}\text { Clinicians perceive } \\
\text { parent prognostic } \\
\text { understanding and } \\
\text { attitudes as the } \\
\text { most common } \\
\text { barriers to } \\
\text { conducting } \\
\text { advance care } \\
\text { discussions. } \\
\text { Educational } \\
\text { interventions aimed } \\
\text { at improving } \\
\text { clinician } \\
\text { knowledge, } \\
\text { attitudes, and skills } \\
\text { in addressing these } \\
\text { barriers may help } \\
\text { HCPs overcome } \\
\text { perceived barriers. }\end{array}$ & $\begin{array}{l}\text { Communication } \\
\text { New resuscitation } \\
\text { order will be } \\
\text { developed to } \\
\text { communicate } \\
\text { overall goals of } \\
\text { care } \\
\text { Training/education } \\
\text { HCPs' ability to } \\
\text { discuss EoLC } \\
\text { with families is a } \\
\text { barrier to } \\
\text { engagement in } \\
\text { ACP }\end{array}$ & $\begin{array}{l}\text { Included } \\
\text { Although the focus of } \\
\text { the study was HCPs, } \\
\text { the research } \\
\text { identified the impact } \\
\text { of their knowledge } \\
\text { and skills on the } \\
\text { process of ACPfYP } \\
\text { Hawker et al, } \\
\text { framework score: } \\
(29 / 36)\end{array}$ \\
\hline
\end{tabular}




\begin{tabular}{|c|c|c|c|c|c|c|c|c|}
\hline & & & $\begin{array}{l}\text { African Americans } \\
\text { and those who } \\
\text { identified as Middle } \\
\text { Eastern each } \\
\text { comprised } 10 \\
\text { participants. } \\
\text { The majority of } \\
\text { respondents } \\
\text { identified as } \\
\text { Catholic ( } n=179) \text { or } \\
\text { Protestant ( } n=234 \text { ); } \\
\text { nondenominational } \\
\text { Christian ( } n=64) \\
\text { and no religion } \\
\text { ( } n=44) \text {. The } \\
\text { remainder of } \\
\text { participants } \\
\text { identified as } \\
\text { Jewish, Hindu, } \\
\text { Mormon, Muslim, } \\
\text { and Buddhis }\end{array}$ & & & & $\begin{array}{l}\text { A family-centred } \\
\text { approach might } \\
\text { encourage people } \\
\text { to engage in ACP }\end{array}$ & \\
\hline $\begin{array}{l}\text { An Exploratory } \\
\text { Survey of End- } \\
\text { of-Life Attitudes, } \\
\text { Beliefs, and } \\
\text { Experiences of } \\
\text { Adolescents } \\
\text { With HIVIAIDS } \\
\text { and Their } \\
\text { Families } \\
44\end{array}$ & $\begin{array}{l}\text { To examine } \\
\text { congruence in } \\
\text { HIV positive } \\
\text { adolescents and } \\
\text { their families' } \\
\text { thoughts about } \\
\text { death and dying. }\end{array}$ & $\begin{array}{l}\text { Survey } \\
\text { administered } \\
\text { within a } \\
\text { randomised } \\
\text { control trial }\end{array}$ & $\begin{array}{l}\text { Medically stable, } \\
\text { English-speaking } \\
\text { adolescents aged } \\
\text { 14-21 years with } \\
\text { HIVIAIDS and their } \\
\text { families }(n=48) \\
\text { Adolescent } \\
\text { participants: female } \\
(n=15) \text { and male } \\
(n=9) \\
\text { Family participants: } \\
\text { female }(n=19) \text { and } \\
\text { male }(n=5)\end{array}$ & US & $\begin{array}{l}\text { Children's } \\
\text { National } \\
\text { Medical } \\
\text { Center and } \\
\text { St. Jude } \\
\text { Children's } \\
\text { Research } \\
\text { Hospital, } \\
\text { Michigan, } \\
\text { Washington }\end{array}$ & $\begin{array}{l}\text { The timing of EoL } \\
\text { conversations and } \\
\text { adolescents' EOL } \\
\text { needs and wishes } \\
\text { are not known by } \\
\text { their families. } \\
\text { Families need help } \\
\text { initiating EoL } \\
\text { conversations to } \\
\text { assure that their } \\
\text { adolescents' EOL } \\
\text { wishes are known } \\
\text { to them }\end{array}$ & $\begin{array}{l}\text { Communication } \\
\text { Needs to be } \\
\text { improved with } \\
\text { young people }\end{array}$ & $\begin{array}{l}\text { Included } \\
\text { This study includes } \\
\text { the engagement of } \\
\text { young people and } \\
\text { their inclusion of their } \\
\text { wishes in their EoL } \\
\text { decisions. } \\
\text { Hawker et al, } \\
\text { framework score: } \\
(30 / 36)\end{array}$ \\
\hline
\end{tabular}




\begin{tabular}{|c|c|c|c|c|c|c|c|c|}
\hline & & & $\begin{array}{l}\text { Black/African } \\
\text { American ( } n=41) \\
\text { and only } 3 \\
\text { participants (all } \\
\text { family members) } \\
\text { were educated to } \\
\text { university level. } \\
\text { Nearly half of the } \\
\text { participants }(n=21) \\
\text { did not have any } \\
\text { qualifications. } \\
\text { Nearly half of the } \\
\text { family groups ( } n=10 \\
\text { out of } 24 \text { ) identified } \\
\text { themselves as } \\
\text { living at or below } \\
\text { the federal poverty } \\
\text { level }\end{array}$ & & & & & \\
\hline $\begin{array}{l}\text { Advance Care } \\
\text { Planning: } \\
\text { Challenges and } \\
\text { Approaches for } \\
\text { Pediatricians }{ }^{24}\end{array}$ & $\begin{array}{l}\text { To review } \\
\text { advance care } \\
\text { planning for } \\
\text { children with life- } \\
\text { threatening or life- } \\
\text { limiting conditions } \\
\text { (LTLLCs) in our } \\
\text { local area }\end{array}$ & $\begin{array}{l}\text { Retrospective } \\
\text { case note } \\
\text { review }\end{array}$ & $\begin{array}{l}\text { Young people aged } \\
0-18 \text { years }(n=20) \\
\text { who were } \\
\text { diagnosed with a } \\
\text { LLC or LTC } \\
\text { Died between } \\
\text { October } 2008 \text { and } \\
\text { March } 2010, \text { which } \\
\text { was caused by the } \\
\text { progressive } \\
\text { disease/underlying } \\
\text { diagnosis }(n=11) \text { or } \\
\text { respiratory } \\
\text { problems }(n=7)\end{array}$ & UK & $\begin{array}{l}\text { Two NHS } \\
\text { Trusts in } \\
\text { Bristol }\end{array}$ & $\begin{array}{l}\text { The numbers of } \\
\text { children living with } \\
\text { LCCs or LTCs are } \\
\text { estimated to be } \\
\text { higher than } \\
\text { previously thought } \\
\text { Advancing } \\
\text { technologies can } \\
\text { sustain life in ways } \\
\text { that were } \\
\text { previously } \\
\text { impossible } \\
\text { The best interests } \\
\text { of the child should } \\
\text { be at the forefront }\end{array}$ & $\begin{array}{l}\text { ACP in practice } \\
\text { - Varying standards } \\
\text { of ACP } \\
\text { Communication } \\
\text { - Using prompts } \\
\text { can help initiate } \\
\text { conversations } \\
\text { about ACP } \\
\text { - Communication } \\
\text { skills are key }\end{array}$ & $\begin{array}{l}\text { Included } \\
\text { This study is about } \\
\text { family engagement in } \\
\text { the ACP process and } \\
\text { includes the } \\
\text { engagement of } \\
\text { young people } \\
\text { Hawker et al, } \\
\text { framework score: } \\
(24 / 36)\end{array}$ \\
\hline
\end{tabular}




\begin{tabular}{|c|c|c|c|c|c|c|c|c|}
\hline & & & & & & $\begin{array}{l}\text { of the EoL decision- } \\
\text { making process } \\
\text { There are clear } \\
\text { benefits of ACP }\end{array}$ & & \\
\hline $\begin{array}{l}\text { Adolescent End } \\
\text { of Life } \\
\text { Preferences and } \\
\text { Congruence } \\
\text { With Their } \\
\text { Parents' } \\
\text { Preferences: } \\
\text { Results of a } \\
\text { Survey of } \\
\text { Adolescents } \\
\text { With Cancer }\end{array}$ & $\begin{array}{l}\text { To examine } \\
\text { baseline } \\
\text { congruence } \\
\text { between the self- } \\
\text { reported needs of } \\
\text { adolescents with } \\
\text { cancer for EoLC } \\
\text { and their families' } \\
\text { perception of } \\
\text { those needs } \\
\text { To better } \\
\text { understand how } \\
\text { adolescents with } \\
\text { cancer approach } \\
\text { EoL issues } \\
\text { Practitioners' } \\
\text { experiences with } \\
\text { the study and } \\
\text { their thoughts } \\
\text { regarding EOL } \\
\text { care for } \\
\text { themselves and } \\
\text { their patients }\end{array}$ & Survey & $\begin{array}{l}\text { English-speaking, } \\
\text { age } 14-21 \text { years, } \\
\text { and were } \\
\text { diagnosed with } \\
\text { cancer }(n=17) \text { and } \\
\text { their family member } \\
(n=17) \\
\text { Mean age of the } \\
\text { adolescents was } 16 \\
\text { years (range } 14-21 ; \\
12 \text { patients ( } 71 \%) \\
\text { were less than } 18) ; \\
63 \% \text { were male, } \\
\text { and } 58 \% \text { were } \\
\text { African-American }\end{array}$ & US & $\begin{array}{l}\text { Adolescents } \\
\text { and families } \\
\text { in the } \\
\text { intervention } \\
\text { arm of the } \\
\text { FAmily } \\
\text { CEntered } \\
\text { Advance } \\
\text { Care } \\
\text { Planning } \\
\text { (ACP) for } \\
\text { Teens with } \\
\text { Cancer } \\
\text { (FACE- TC) } \\
\text { study }\end{array}$ & $\begin{array}{l}\text { Adolescents with } \\
\text { cancer were } \\
\text { comfortable } \\
\text { discussing EoL, } \\
\text { and the majority } \\
\text { preferred to talk } \\
\text { about EoL issues } \\
\text { before they are } \\
\text { facing EoL } \\
\text { Important facets of } \\
\text { adolescents' EoL } \\
\text { wishes were not } \\
\text { known by their } \\
\text { families, reinforcing } \\
\text { the importance of } \\
\text { eliciting individual } \\
\text { preferences and } \\
\text { engaging dyads so } \\
\text { parents can } \\
\text { understand their } \\
\text { children's wishes }\end{array}$ & $\begin{array}{ll}\text { ACP in practice } \\
\text { - } & \text { Need improved } \\
\text { information about } & \text { hospice services } \\
\text { - } & \text { Not always } \\
& \text { congruence the } \\
& \text { family about } \\
& \text { location of death } \\
\text { Training/education } & \\
\text { - Improved } \\
\text { communication } \\
\text { between HCPs } \\
\text { and families }\end{array}$ & $\begin{array}{l}\text { Included } \\
\text { Identifies that young } \\
\text { people can/should be } \\
\text { engaged with } \\
\text { planning their own } \\
\text { care } \\
\text { Hawker et al, } \\
\text { framework score: } \\
(26 / 36)\end{array}$ \\
\hline $\begin{array}{l}\text { Pediatric } \\
\text { Advance Care } \\
\text { Planning: A } \\
\text { Systematic } \\
\text { Review }^{46}\end{array}$ & $\begin{array}{l}\text { To assess current } \\
\text { practices, effects, } \\
\text { and perspectives } \\
\text { of pACP }\end{array}$ & $\begin{array}{l}\text { Systematic } \\
\text { review }\end{array}$ & $\begin{array}{l}5 \text { qualitative and } 8 \\
\text { quantitative studies. } \\
\text { Only } 3 \text { pACP } \\
\text { programs were } \\
\text { identified, all from } \\
\text { the United States }\end{array}$ & US & $\begin{array}{l}\text { A range of } \\
\text { settings: } \\
\text { Inpatient/ } \\
\text { outpatient }\end{array}$ & $\begin{array}{l}\text { There are few } \\
\text { systematic pACP } \\
\text { programs } \\
\text { worldwide and } \\
\text { none in Europe }\end{array}$ & $\begin{array}{l}\text { ACP in practice } \\
\text { - } \text { Reluctance to } \\
\text { engage in ACP } \\
\text { discussions if the } \\
\text { prognosis was } \\
\text { poor }\end{array}$ & $\begin{array}{l}\text { Included } \\
\text { Review included } \\
\text { attitudes of young } \\
\text { people in the } \\
\text { EoL/ACP process }\end{array}$ \\
\hline
\end{tabular}




\begin{tabular}{|c|c|c|c|c|c|c|c|c|}
\hline & & & $\begin{array}{l}\text { Participants ranged } \\
\text { in age from } 2 \\
\text { months to } 37 \text { years } \\
\text { old }\end{array}$ & & $\begin{array}{l}\text { and/or clinic } \\
(n=5) \\
\text { ICU }(n=1) \\
\text { School }(n=1) \\
\text { Unspecified } \\
(n=4)\end{array}$ & $\begin{array}{l}\text { Future research } \\
\text { should investigate } \\
\text { the needs of all } \\
\text { stakeholders, } \\
\text { particularly HCPs }\end{array}$ & & $\begin{array}{l}\text { Hawker et al, } \\
\text { framework score: } \\
(33 / 36)\end{array}$ \\
\hline $\begin{array}{l}\text { Pediatric } \\
\text { advance care } \\
\text { planning from } \\
\text { the perspective } \\
\text { of health care } \\
\text { professionals: A } \\
\text { qualitative } \\
\text { interview study }\end{array}$ & $\begin{array}{l}\text { To investigate } \\
\text { attitudes and } \\
\text { needs of HCPs } \\
\text { with regard to } \\
\text { pACP } \\
\text { To investigate } \\
\text { attitudes, barriers, } \\
\text { and benefits as } \\
\text { well as } \\
\text { requirements for } \\
\text { pACP from the } \\
\text { view of HCPs }\end{array}$ & $\begin{array}{l}\text { Qualitative } \\
\text { interview study }\end{array}$ & $\begin{array}{l}17 \text { HCPs } \\
\text { (physicians: } n=9 ; \\
\text { nurses: } n=6 ; \text { social } \\
\text { professionals } n=2 \text { ) } \\
\text { representing a } \\
\text { range of paediatric } \\
\text { disciplines } \\
\text { An average age of } \\
46 \text { years and an } \\
\text { average of } 21 \\
\text { years' experience } \\
\text { Male }(n=6) ; \text { female } \\
(n=11)\end{array}$ & Germany & $\begin{array}{l}\begin{array}{l}\text { Hospital care } \\
(n=7)\end{array} \\
\text { Outpatient } \\
\text { care }(n=8) \\
\text { Care facility } \\
(n=4) \\
\text { Some } \\
\text { participants } \\
\text { were working } \\
\text { in more than } \\
\text { one care } \\
\text { setting in } \\
\text { Munich and } \\
\text { surrounding } \\
\text { areas }\end{array}$ & $\begin{array}{l}\text { There is a need for } \\
\text { paediatric ACP } \\
\text { There are several } \\
\text { barriers to its } \\
\text { implementation }\end{array}$ & $\begin{array}{c}\text { ACP in practice } \\
\text { - } \quad \text { Problems related } \\
\text { to ACP are about } \\
\text { HCP discomfort } \\
\text { and uncertainty } \\
\text { - } \quad \text { Potential barriers } \\
\text { and facilitators to } \\
\text { ACP are identified } \\
\text { - Evidence from } \\
\text { adult ACP may } \\
\text { help to inform the } \\
\text { development of } \\
\text { ACPfYP } \\
\text { Training/education } \\
\text { - Focus for HCPs' } \\
\text { training is } \\
\text { identified }\end{array}$ & $\begin{array}{l}\text { Included } \\
\text { Identified the } \\
\text { engagement of } \\
\text { young people from } \\
\text { HCPs' point of view } \\
\text { Hawker et al, } \\
\text { framework score: } \\
(33 / 36)\end{array}$ \\
\hline $\begin{array}{l}\text { A randomized } \\
\text { clinical trial of } \\
\text { adolescents with } \\
\text { HIV/ AIDS: } \\
\text { pediatric } \\
\text { advance care } \\
\text { planning } 47\end{array}$ & $\begin{array}{l}\text { To determine if } \\
\text { paediatric } \\
\text { advance care } \\
\text { planning (pACP) } \\
\text { increases } \\
\text { adolescent/ family } \\
\text { congruence in } \\
\text { end-of-life (EOL) } \\
\text { treatment } \\
\text { preferences } \\
\text { longitudinally }\end{array}$ & $\begin{array}{l}\text { Randomised } \\
\text { clinical trial }\end{array}$ & $\begin{array}{l}\text { Adolescents aged } \\
\text { 14-21 years with } \\
\text { HIVIAIDS and their } \\
\text { families ( } n=105 \\
\text { dyads). } \\
\text { Adolescents- } \\
\text { Male }(n=29) ; \\
\text { female }(n=25)\end{array}$ & US & $\begin{array}{l}6 \text { unspecified } \\
\text { paediatric } \\
\text { hospital- } \\
\text { based HIV } \\
\text { clinics, } \\
\text { located in } \\
\text { high mortality } \\
\text { urban areas } \\
\text { in the } \\
\text { Southern US }\end{array}$ & $\begin{array}{l}\text { A structured pACP } \\
\text { intervention was } \\
\text { effective in: } \\
\text { Increasing } \\
\text { congruence in EOL } \\
\text { treatment } \\
\text { preferences } \\
\text { between } \\
\text { adolescents and } \\
\text { their families }\end{array}$ & $\begin{array}{ll}\text { ACP in practice } \\
\text { - } & \text { ACP is more } \\
\text { effective when } \\
\text { intervention is } \\
\text { targeted } \\
\text { - } \\
\text { Targeted ACP } \\
\text { positively } \\
\text { influenced } \\
\text { relationships and } \\
\text { communication }\end{array}$ & $\begin{array}{l}\text { Included } \\
\text { Review included } \\
\text { attitudes of young } \\
\text { people in the } \\
\text { EoL/ACP process } \\
\text { Hawker et al, } \\
\text { framework score: } \\
(35 / 36)\end{array}$ \\
\hline
\end{tabular}




\begin{tabular}{|c|c|c|c|c|c|c|c|c|}
\hline & & & $\begin{array}{l}\text { Age range=14-20 } \\
\text { years; mean } \\
\text { age=18 years; } \\
\text { Black African- } \\
\text { American }(n=50) ; \\
\text { Hispanic/Latino/non } \\
\text {-African ( } n=4) \text {. } \\
\text { No qualifications } \\
\text { from high school } \\
(n=29) \\
\text { At or below the } \\
\text { federal poverty line } \\
\text { ( } n=28) \\
\text { One-third had an } \\
\text { AIDS diagnosis. }\end{array}$ & & & $\begin{array}{l}\text { Engaging } \\
\text { adolescents/familie } \\
\text { s to begin these } \\
\text { conversations early } \\
\text { and to continue } \\
\text { these } \\
\text { conversations over } \\
\text { time } \\
\text { Demonstrating } \\
\text { safety e.g. such } \\
\text { topics as using a } \\
\text { seat belt and } \\
\text { having a smoke } \\
\text { detector in the } \\
\text { home }\end{array}$ & & \\
\hline $\begin{array}{l}\text { A Longitudinal, } \\
\text { Randomized, } \\
\text { Controlled Trial } \\
\text { of Advance Care } \\
\text { Planning for } \\
\text { Teens With } \\
\text { Cancer: Anxiety, } \\
\text { Depression, } \\
\text { Quality of Life, } \\
\text { Advance } \\
\text { Directives, } \\
\text { Spirituality }{ }^{48}\end{array}$ & $\begin{array}{l}\text { To test the } \\
\text { feasibility, } \\
\text { acceptability and } \\
\text { safety of a } \\
\text { paediatric } \\
\text { advance care } \\
\text { planning } \\
\text { intervention }\end{array}$ & $\begin{array}{l}\text { Randomised } \\
\text { controlled trial }\end{array}$ & $\begin{array}{l}\text { Adolescent (age } \\
\text { 14-21 years)/family } \\
\text { dyads }(n=30) \text { with a } \\
\text { cancer diagnosis } \\
\text { Young people: } \\
\text { Male }(n=18) \text {, } \\
\text { female }(n=12) ; \\
\text { Race: Asian }(n=2) ; \\
\text { Black ( } n=13) ; \text { White } \\
\text { ( } n=15) \\
\text { A range of } \\
\text { diagnoses: } \\
\text { Leukaemia }(n=14) ; \\
\text { Lymphoma }(n=2) ; \\
\text { solid tumour }(n=6) ; \\
\text { brain tumour }(n=8) \\
\text { The majority }(n=24) \\
\text { had no educational } \\
\text { qualifications }\end{array}$ & US & $\begin{array}{l}\text { Unidentified } \\
\text { large urban } \\
\text { children's } \\
\text { hospital in- } \\
\text { patient unit, } \\
\text { outpatient } \\
\text { clinic and } \\
\text { patients' } \\
\text { home }\end{array}$ & $\begin{array}{l}\text { Family-Centered } \\
\text { Advance Care } \\
\text { Planning for Teens } \\
\text { With Cancer } \\
\text { demonstrated } \\
\text { feasibility and } \\
\text { acceptability. } \\
\text { Courageous } \\
\text { adolescents } \\
\text { willingly } \\
\text { participated in } \\
\text { highly structured, } \\
\text { in-depth paediatric } \\
\text { advance care } \\
\text { planning } \\
\text { conversations } \\
\text { safely }\end{array}$ & $\begin{array}{l}\mathrm{ACP} \text { in practice } \\
\text { - Structured ACP } \\
\text { can improve } \\
\text { participation in } \\
\text { the ACP process } \\
\text { and } \\
\text { communication; } \\
\text { and reduce stress } \\
\text { and anxiety }\end{array}$ & $\begin{array}{l}\text { Included } \\
\text { Study discusses } \\
\text { ACPfYP with the } \\
\text { target age group } \\
\\
\text { Hawker et al, } \\
\text { framework score: } \\
(35 / 36)\end{array}$ \\
\hline
\end{tabular}




\begin{tabular}{|c|c|c|c|c|c|c|c|c|}
\hline & & & $\begin{array}{l}\text { Family members: } \\
\text { Male }(n=2) \text {, female } \\
(n=28) \\
\text { Race: Asian }(n=1) ; \\
\text { Black }(n=13) ; \text { White } \\
(n=13) ; \text { declined } \\
(n=1) \\
\text { No high school } \\
\text { diploma or were in } \\
\text { high school ( } n=24) \\
\text { An income }>300 \% \\
\text { federal poverty line } \\
\text { ( } n=14), \text { with only } 4 \\
\text { families reporting } \\
\text { an income equal to } \\
\text { or below the federal } \\
\text { poverty line }\end{array}$ & & & & & \\
\hline $\begin{array}{l}\text { Family-Centered } \\
\text { Advance Care } \\
\text { Planning for } \\
\text { Teens With } \\
\text { Cancer }^{45}\end{array}$ & $\begin{array}{l}\text { To examine the } \\
\text { efficacy of family- } \\
\text { centred ACP }\end{array}$ & $\begin{array}{l}\text { Randomised } \\
\text { control trial }\end{array}$ & $\begin{array}{l}\text { Young people } \\
(n=30) \text { aged } 14 \text { to } \\
21 \text { years with } \\
\text { cancer and their } \\
\text { surrogates or } \\
\text { families ( } n=30) \\
\text { Young people: } \\
\text { Male }(n=18) ; \\
\text { female }(n=12) \\
\text { Race: Asian }(n=2) ; \\
\text { Black ( } n=13) ; \text { White } \\
\text { ( } n=15) \\
\text { Condition: } \\
\text { Leukaemia }(n=14) ; \\
\text { Lymphoma }(n=2) ; \\
\text { Solid tumour }(n=6) ; \\
\text { Brain tumour }(n=8) \\
\text { Education: }\end{array}$ & US & $\begin{array}{l}\text { Children's } \\
\text { National } \\
\text { Medical } \\
\text { Center, } \\
\text { Washington } \\
\text { DC }\end{array}$ & $\begin{array}{l}\text { ACP enabled } \\
\text { families to } \\
\text { understand and } \\
\text { honour their } \\
\text { adolescents' } \\
\text { wishes. } \\
\text { Intervention dyads } \\
\text { were more likely } \\
\text { than controls to } \\
\text { limit treatments. } \\
\text { Underserved } \\
\text { African American } \\
\text { families were } \\
\text { willing to participate }\end{array}$ & $\begin{array}{cl}\text { ACP in practice } \\
\text { - } & \text { A structured ACP } \\
\text { process can } \\
\text { improve } \\
\text { communication } \\
\text { and engagement } \\
\text { of young people } \\
\text { and empower } \\
\text { them } \\
\text { Communication } \\
\text { A structured ACP } \\
\text { process can } \\
\text { improve } \\
\text { clinicians' } \\
\text { communication } \\
\text { A structured } \\
\text { process can help } \\
\text { engagement of }\end{array}$ & $\begin{array}{l}\text { Included } \\
\text { Study discusses } \\
\text { ACPfYP with the } \\
\text { target age group. } \\
\text { The inclusion of } \\
\text { young people's } \\
\text { wishes is also part of } \\
\text { the study. } \\
\text { Hawker et al, } \\
\text { framework score: } \\
\text { (35/36) }\end{array}$ \\
\hline
\end{tabular}




\begin{tabular}{|c|c|c|c|c|c|c|c|c|}
\hline & & & $\begin{array}{l}\text { No high school } \\
\text { diploma or were in } \\
\text { high school ( } n=24) \\
\text { Families/surrogates } \\
\vdots \\
\text { Male ( } n=2) \text {; female } \\
(n=28) \\
\text { Race: Asian ( } n=1) ; \\
\text { Black ( } n=13) ; \text { White } \\
(n=15) ; \text { declined } \\
(n=1) \\
\text { Had at least some } \\
\text { education to } \\
\text { college/higher } \\
\text { education level } \\
\text { ( } n=24) \\
\text { An income }>300 \% \\
\text { federal poverty line } \\
\text { ( } n=14), \text { with only } 4 \\
\text { families reporting } \\
\text { an income equal to } \\
\text { or below the federal } \\
\text { poverty line }\end{array}$ & & & & $\begin{array}{l}\text { young people and } \\
\text { allow them to } \\
\text { express their } \\
\text { wishes } \\
\text { Relationships } \\
\text { - A structured } \\
\text { process provides } \\
\text { a potential for } \\
\text { avoiding conflict }\end{array}$ & \\
\hline $\begin{array}{l}\text { What Do } \\
\text { Adolescents } \\
\text { Want? An } \\
\text { Exploratory } \\
\text { Study } \\
\text { Regarding End- } \\
\text { of-Life Decision- } \\
\text { making } 56\end{array}$ & $\begin{array}{l}\text { To explore } \\
\text { whether } \\
\text { differences exist } \\
\text { between } \\
\text { chronically ill and } \\
\text { healthy } \\
\text { adolescents with } \\
\text { regard to their } \\
\text { attitudes about } \\
\text { EoL issues }\end{array}$ & $\begin{array}{l}\text { Focus group } \\
\text { with young } \\
\text { people aged } \\
>18 \text { and } \\
\text { interviews with } \\
\text { HCPs } \\
\text { Focus group } \\
\text { and interviews } \\
\text { helped } \\
\text { develop a 25- } \\
\text { item survey, }\end{array}$ & $\begin{array}{l}\text { Unspecified HCPs } \\
\text { Young people: } \\
\text { Healthy: } \\
\text { Aged } 14-21(n=25) \\
\text { Male }(n=6) ; \text { female } \\
(n=19) \\
\text { Ethnicity: African- } \\
\text { American ( } n=25) ; \\
\text { Caucasian; } \\
\text { Hispanic }\end{array}$ & US & $\begin{array}{l}\text { Children's } \\
\text { National } \\
\text { Medical } \\
\text { Center, } \\
\text { Washington } \\
\text { DC }\end{array}$ & $\begin{array}{l}\text { Teens without a } \\
\text { chronic illness have } \\
\text { thought about EoL } \\
\text { issues and have } \\
\text { opinions similar to } \\
\text { those of chronically } \\
\text { ill teens. } \\
\text { Most healthy and } \\
\text { chronically ill } \\
\text { adolescents do } \\
\text { want to be involved }\end{array}$ & $\begin{array}{l}\text { ACP in practice } \\
\text { - } \\
\text { Palliative care } \\
\text { should be } \\
\text { integrated from } \\
\text { the time of } \\
\text { diagnosis } \\
\text { - } \quad \text { Participating in } \\
\text { the ACP process } \\
\text { gives young } \\
\text { people some } \\
\text { control over what } \\
\text { happens to them }\end{array}$ & $\begin{array}{l}\text { Included } \\
\text { Study discusses } \\
\text { ACPfYP with the } \\
\text { target age group. } \\
\text { The inclusion of } \\
\text { young people's } \\
\text { wishes is also part of } \\
\text { the study }\end{array}$ \\
\hline
\end{tabular}




\begin{tabular}{|c|c|c|c|c|c|c|c|c|}
\hline & & $\begin{array}{l}\text { which was } \\
\text { then used to } \\
\text { gather the } \\
\text { views of young } \\
\text { people }\end{array}$ & $\begin{array}{l}\text { Chronically ill } \\
\text { Aged 13-21 }(n=25) \\
\text { Male }(n=9) ; \text { female } \\
(n=16) \\
\text { Ethnicity: African- } \\
\text { American }(n=19) ; \\
\text { Caucasian }(n=3) ; \\
\text { Hispanic }(n=3)\end{array}$ & & & $\begin{array}{l}\text { in shared decision- } \\
\text { making. } \\
\text { The EoL decision- } \\
\text { making process } \\
\text { should be } \\
\text { individualised }\end{array}$ & $\begin{array}{ll}-\quad & \text { Reliance on } \\
& \text { guidelines and } \\
\text { recommendations } \\
\text { to overcome } \\
\text { barriers } \\
\text { Communication } \\
\text { - Tension } \\
\text { surrounding the } \\
\text { communication } \\
\text { and timing of } \\
\text { communication } \\
\text { about ACP }\end{array}$ & $\begin{array}{l}\text { Hawker et al, } \\
\text { framework score: } \\
(33 / 36)\end{array}$ \\
\hline $\begin{array}{l}\text { Development, } \\
\text { Feasibility, and } \\
\text { Acceptability of } \\
\text { the Family/ } \\
\text { Adolescent- } \\
\text { Centered } \\
\text { (FACE) } \\
\text { Advance Care } \\
\text { Planning } \\
\text { Intervention for } \\
\text { Adolescents } \\
\text { with HIV49 }\end{array}$ & $\begin{array}{l}\text { To develop, } \\
\text { adapt, and ensure } \\
\text { feasibility, } \\
\text { acceptability, and } \\
\text { safety of the } \\
\text { Family/ } \\
\text { Adolescent- } \\
\text { Centered (FACE) } \\
\text { Advance Care } \\
\text { Planning } \\
\text { intervention }\end{array}$ & $\begin{array}{l}\text { Two-group, } \\
\text { randomised, } \\
\text { controlled trial }\end{array}$ & $\begin{array}{l}\text { Young people: } \\
\text { Aged 14-21 }(n=38) \\
\text { Male }(n=15) ; \\
\text { female }(n=23) \\
\text { Race/Ethnicity: } \\
\text { Black/African } \\
\text { American }(n=35) ; \\
\text { White/Caucasian } \\
\text { ( } n=2) ; \text { American } \\
\text { Indian/Alaskan } \\
(n=1) \\
\text { The majority of } \\
\text { participants ( } n=22) \\
\text { had no high school } \\
\text { diploma or were in } \\
\text { high school }(n=22) \\
\text { The majority of } \\
\text { participants }(n=35) \\
\text { were in permanent } \\
\text { housing. }\end{array}$ & US & $\begin{array}{l}\text { Two } \\
\text { unspecified } \\
\text { hospital- } \\
\text { based } \\
\text { outpatient } \\
\text { clinics in } \\
\text { Washington, } \\
\text { D.C. and } \\
\text { Memphis, } \\
\text { Tennessee }\end{array}$ & $\begin{array}{l}\text { Existing ACP } \\
\text { models can be } \\
\text { adapted for age, } \\
\text { disease, and } \\
\text { culture. } \\
\text { Young people with } \\
\text { HIVIAIDS were } \\
\text { satisfied with an } \\
\text { ACP approach that } \\
\text { facilitated } \\
\text { discussion about } \\
\text { their EoL wishes } \\
\text { with their families. } \\
\text { Families } \\
\text { acknowledged a } \\
\text { LTC and were } \\
\text { willing to initiate } \\
\text { EoL conversations } \\
\text { when their children } \\
\text { were medically } \\
\text { stable }\end{array}$ & $\begin{array}{l}\text { ACP in practice } \\
\text { - } \\
\text { A structured } \\
\text { process is more } \\
\text { effective at } \\
\text { engaging the } \\
\text { target population } \\
\text { Communication } \\
\text { - } \\
\text { Positive } \\
\text { contribution of } \\
\text { conversations } \\
\text { about EoLC } \\
\text { Relationships } \\
\text { Potential conflict } \\
\text { between young } \\
\text { people and family } \\
\text { members }\end{array}$ & $\begin{array}{l}\text { Included } \\
\text { Study discusses } \\
\text { ACPfYP with the } \\
\text { target age group. } \\
\text { The inclusion of } \\
\text { young people's } \\
\text { wishes is also part of } \\
\text { the study } \\
\text { Hawker et al, } \\
\text { framework score: } \\
\text { (35/36) }\end{array}$ \\
\hline
\end{tabular}




\begin{tabular}{|c|c|c|c|c|c|c|c|c|}
\hline & & & $\begin{array}{l}\text { There was a spread } \\
\text { of different income } \\
\text { levels } \\
\text { The majority }(n=32) \\
\text { were heterosexual } \\
\text { The majority }(n=36) \\
\text { were single }\end{array}$ & & & & & \\
\hline $\begin{array}{l}\text { Engaging } \\
\text { College } \\
\text { Undergraduates } \\
\text { in Advance Care } \\
\text { Planning }{ }^{57}\end{array}$ & $\begin{array}{l}\text { To examine the } \\
\text { reactions of } \\
\text { college students } \\
\text { following the } \\
\text { completion of } \\
\text { their advance } \\
\text { care plans and } \\
\text { then sharing } \\
\text { these plans with } \\
\text { friends and family }\end{array}$ & $\begin{array}{l}\text { 1. Students } \\
\text { received a } \\
90 \text {-min } \\
\text { lecture on } \\
\text { the } \\
\text { importance } \\
\text { of ACP } \\
\text { 2. Students } \\
\text { participated } \\
\text { in } \\
\text { facilitated } \\
\text { discussion } \\
\text { around } \\
\text { completing } \\
\text { their ACP } \\
\text { 3. Students } \\
\text { were asked } \\
\text { to present } \\
\text { their ACP } \\
\text { to key } \\
\text { family } \\
\text { members } \\
\text { and friends } \\
\text { 4. Students } \\
\text { were asked } \\
\text { to write a 5- } \\
\text { page } \\
\text { reflection }\end{array}$ & $\begin{array}{l}3^{\text {rd }} \text { and } 4^{\text {th }} \text { year } \\
\text { undergraduate } \\
\text { students }\end{array}$ & US & $\begin{array}{l}\text { An } \\
\text { unspecified } \\
\text { large } \\
\text { Midwestern } \\
\text { university }\end{array}$ & $\begin{array}{l}\text { Students reported } \\
\text { that while } \\
\text { completing their } \\
\text { ACPs created } \\
\text { many emotions, } \\
\text { they found the } \\
\text { experience to be } \\
\text { valuable and } \\
\text { facilitated } \\
\text { conversations with } \\
\text { family and friends } \\
\text { about end-of-life } \\
\text { care that may not } \\
\text { have occurred } \\
\text { otherwise }\end{array}$ & $\begin{array}{ll}\text { ACP in practice } \\
\text { - } & \text { Self-protective } \\
& \text { disengagement } \\
& \text { from some } \\
& \text { students } \\
\text { - } & \text { Worry, fear and } \\
& \text { anxiety } \\
\text { - } & \text { Positive growth } \\
\text { (empowerment) } \\
\text { - ACPs can foster } \\
\text { effective } \\
\text { communication } \\
\text { Training/Education } \\
\text { - Educators have a } \\
\text { key role in starting } \\
\text { discussions with } \\
\text { young people } \\
\text { about their ACP } \\
\text { Relationships } \\
\text { Choosing the } \\
\text { right family } \\
\text { member to be } \\
\text { their decision- } \\
\text { maker }\end{array}$ & $\begin{array}{l}\text { Included } \\
\text { The study includes } \\
\text { the views of young } \\
\text { people who match } \\
\text { my criteria. It also } \\
\text { explores how their } \\
\text { views can be } \\
\text { incorporated into } \\
\text { their own ACP } \\
\text { alongside their } \\
\text { family's views } \\
\text { Hawker et al, } \\
\text { framework score: } \\
\text { (28/36) }\end{array}$ \\
\hline
\end{tabular}




\begin{tabular}{|c|c|c|c|c|c|c|c|c|}
\hline & & $\begin{array}{l}\text { paper on } \\
\text { the } \\
\text { experience } \\
\text { of } \\
\text { completing } \\
\text { their ACP }\end{array}$ & & & & & & \\
\hline $\begin{array}{l}\text { How I Wish to } \\
\text { be } \\
\text { Remembered: } \\
\text { The Use of an } \\
\text { Advance Care } \\
\text { Planning } \\
\text { Document in } \\
\text { Adolescent and } \\
\text { Young Adult } \\
\text { Populations }^{50}\end{array}$ & $\begin{array}{l}\text { To explore } \\
\text { whether } \\
\text { adolescents and } \\
\text { young adults } \\
\text { living with a LLC } \\
\text { find it acceptable } \\
\text { and helpful to } \\
\text { have a planning } \\
\text { document to } \\
\text { share their wishes } \\
\text { and thoughts } \\
\text { regarding EOL } \\
\text { care. If so, to } \\
\text { learn about } \\
\text { specific concerns } \\
\text { adolescents and } \\
\text { young adults feel } \\
\text { are important to } \\
\text { include in such a } \\
\text { document. }\end{array}$ & Survey & $\begin{array}{l}\begin{array}{l}20 \text { study } \\
\text { participants }\end{array} \\
\text { Male }(n=10) ; \\
\text { female }(n=10) \\
\text { Age range: } \\
\text { 16-19 years }(n=9) \\
\text { 20-28 years }(n=11) \\
\text { Race: } \\
\text { Caucasian }(n=10) \\
\text { African American } \\
\text { ( } n=8) \\
\text { Hispanic }(n=2) \\
\text { Diagnosis: } \\
\text { Cancer }(n=10) \\
\text { HIV }(n=10)\end{array}$ & US & $\begin{array}{l}\text { National } \\
\text { Cancer } \\
\text { Institute, } \\
\text { Pediatric } \\
\text { Oncology } \\
\text { Branch } \\
\text { Maryland }\end{array}$ & $\begin{array}{l}\text { ACP may be } \\
\text { appropriate and } \\
\text { helpful for young } \\
\text { people living with a } \\
\text { serious illness. } \\
\text { Future research } \\
\text { should further } \\
\text { validate the } \\
\text { preferences } \\
\text { identified by } \\
\text { participants and } \\
\text { explore whether an } \\
\text { age-appropriate } \\
\text { document can } \\
\text { improve } \\
\text { communication with } \\
\text { family and staff in } \\
\text { EoL care }\end{array}$ & $\begin{array}{cl}\text { ACP in practice } \\
\text { - } \\
\text { moung people } \\
\text { may be less } \\
\text { concerned with } \\
\text { legalities and } \\
\text { medical decision- } \\
\text { making than } \\
\text { treatment, } \\
\text { memories and } \\
\text { those they leave } \\
\text { behind } \\
\text { Communication } \\
\text { ACP may foster } \\
\text { communication } \\
\text { within the family }\end{array}$ & $\begin{array}{l}\text { Included } \\
\text { Discussion about the } \\
\text { importance of } \\
\text { including young } \\
\text { people in their own } \\
\text { ACP } \\
\text { Hawker et al, } \\
\text { framework score: } \\
(29 / 36)\end{array}$ \\
\hline $\begin{array}{l}\text { Allowing } \\
\text { Adolescents and } \\
\text { Young Adults to } \\
\text { Plan Their End- } \\
\text { of-Life Care }{ }^{53}\end{array}$ & $\begin{array}{l}\text { To assess and } \\
\text { compare the } \\
\text { usefulness, } \\
\text { helpfulness, and } \\
\text { stress associated } \\
\text { with reviewing a } \\
\text { previously } \\
\text { adapted advance } \\
\text { care planning } \\
\text { guide, My }\end{array}$ & $\begin{array}{l}\text { Ranking } \\
\text { exercise on My } \\
\text { Thoughts, My } \\
\text { Wishes, My } \\
\text { Voice and, } \\
\text { Five Wishes }\end{array}$ & $\begin{array}{l}\text { Fifty-two } \\
\text { participants living } \\
\text { with metastatic or } \\
\text { recurrent cancer } \\
(n=16) \text { or HIV } \\
\text { infection }(n=26) \\
\text { Aged 16-28 years }\end{array}$ & US & $\begin{array}{l}\text { Pediatric } \\
\text { Oncology } \\
\text { Branch of the } \\
\text { National } \\
\text { Cancer } \\
\text { Institute and } \\
\text { from } \\
\text { Georgetown } \\
\text { University } \\
\text { Hospital }\end{array}$ & $\begin{array}{l}\text { Seriously ill young } \\
\text { people benefit from } \\
\text { being involved in } \\
\text { their EoL treatment } \\
\text { and care plans. } \\
\text { An age-appropriate } \\
\text { ACP can provide a } \\
\text { sense of trust with } \\
\text { the medical team, }\end{array}$ & $\begin{array}{l}\text { ACP in practice } \\
\text { - It is important to } \\
\text { engage seriously } \\
\text { ill young people in } \\
\text { their ACP } \\
\text { - A structured } \\
\text { document allows } \\
\text { greater } \\
\text { engagement of } \\
\text { the young people }\end{array}$ & $\begin{array}{l}\text { Included } \\
\text { Identifies the } \\
\text { importance of } \\
\text { engaging young } \\
\text { people in their ACP } \\
\text { and suggests how } \\
\text { young people can be } \\
\text { engaged }\end{array}$ \\
\hline
\end{tabular}




\begin{tabular}{|c|c|c|c|c|c|c|c|c|}
\hline & $\begin{array}{l}\text { Thoughts, My } \\
\text { Wishes, My } \\
\text { Voice, in } \\
\text { comparison with } \\
\text { the widely used } \\
\text { adult document } \\
\text { Five Wishes by } \\
\text { adolescents and } \\
\text { young adults } \\
\text { (AYAs) living with } \\
\text { a serious illness }\end{array}$ & & $\begin{array}{l}\text { Male (46\%); } \\
\text { Female (54\%) } \\
\text { Race: } \\
\text { African American } \\
(44 \%) \\
\text { White (33\%) } \\
\text { Hispanic/Latino } \\
(14 \%) \\
\text { Asian/Pacific } \\
\text { Islander }(2 \%) \\
\text { Biracial }(4 \%) \\
\text { Other }(2 \%)\end{array}$ & & & $\begin{array}{l}\text { their family, and } \\
\text { providing some } \\
\text { measure of control } \\
\text { and independence } \\
\text { for the young } \\
\text { person } \\
\text { Certain items are } \\
\text { important in a } \\
\text { specific document } \\
\text { that allows } \\
\text { compassionate and } \\
\text { self-directed care, } \\
\text { support, and } \\
\text { comfort both before } \\
\text { and after death. } \\
\text { Voicing choices } \\
\text { allows young } \\
\text { people to reflect on } \\
\text { their life and to } \\
\text { make choices } \\
\text { about what } \\
\text { nurtures, protects, } \\
\text { and affirms their } \\
\text { remaining life and } \\
\text { how they wish to be } \\
\text { remembered into } \\
\text { the future }\end{array}$ & $\begin{array}{l}\text { and potential for } \\
\text { compassionate } \\
\text { and self-directed } \\
\text { care, support and } \\
\text { comfort both } \\
\text { before and after } \\
\text { death } \\
\text { Relationships } \\
\text { ACP can create a } \\
\text { sense of trust } \\
\text { between young } \\
\text { people, their } \\
\text { family and the } \\
\text { medical team }\end{array}$ & $\begin{array}{l}\text { Hawker et al, } \\
\text { framework score: } \\
(30 / 36)\end{array}$ \\
\hline $\begin{array}{l}\text { Differences } \\
\text { between } \\
\text { Pediatricians } \\
\text { and Internists in } \\
\text { Advance Care } \\
\text { Planning for } \\
\text { Adolescents } \\
\text { with Cancer } \\
\text { w1 }\end{array}$ & $\begin{array}{l}\text { To evaluate } \\
\text { differences } \\
\text { between } \\
\text { paediatricians and } \\
\text { internists in the } \\
\text { practice of and } \\
\text { barriers to }(A C P)\end{array}$ & $\begin{array}{l}\text { Self-reported } \\
\text { questionnaire }\end{array}$ & $\begin{array}{l}\begin{array}{l}\text { Paediatricians } \\
(n=227)\end{array} \\
\text { Male }(n=174) ; \\
\text { female }(n=53) \\
\text { Age: } 47.6 \pm 7.9\end{array}$ & Japan & $\begin{array}{l}\text { Japanese } \\
\text { board- } \\
\text { certified } \\
\text { haematology } \\
\text {-ists }\end{array}$ & $\begin{array}{l}\text { Paediatricians were } \\
\text { less likely than } \\
\text { internists to discuss } \\
\text { ACP and advance } \\
\text { directives with } \\
\text { patients, and both } \\
\text { paediatricians and } \\
\text { internists tended to }\end{array}$ & $\begin{array}{ll}\text { ACP in practice } \\
\text { - Specialists more } \\
\text { likely than other } \\
\text { HCPs to discuss } \\
\text { ACP } \\
\text { Barriers to ACP } \\
\text { tabulated - } \\
\text { specialists }\end{array}$ & $\begin{array}{l}\text { Included } \\
\text { Discussion about the } \\
\text { importance of } \\
\text { including young } \\
\text { people in their own } \\
\text { ACP and the } \\
\text { potential barriers and }\end{array}$ \\
\hline
\end{tabular}




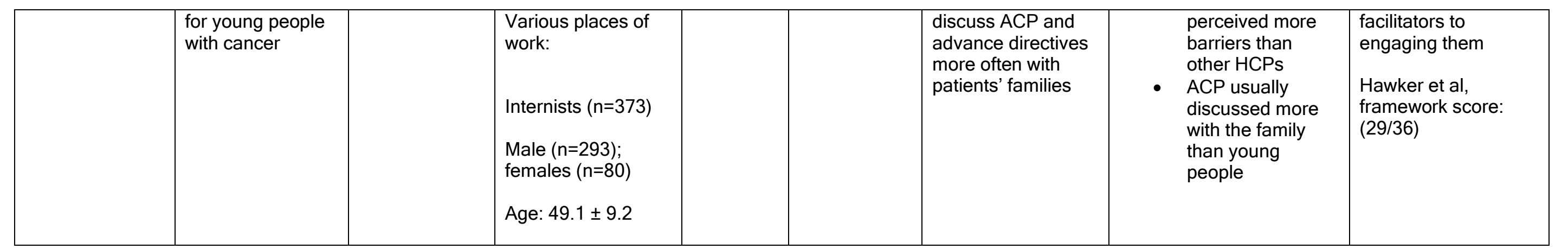

The studies generally covered multiple themes. Only one study ${ }^{44}$ covered a single theme. The theme(s) covered by each individual study are summarised in Table 4.

Table 4 - Summary of the themes covered by each study

\begin{tabular}{|c|c|c|c|c|}
\hline $\begin{array}{l}\text { Study author(s) and date of } \\
\text { publication }\end{array}$ & $\begin{array}{c}\text { Theme } 1 \\
\text { ACP in practice }\end{array}$ & $\begin{array}{c}\text { Theme } 2 \\
\text { Communication }\end{array}$ & $\begin{array}{c}\text { Theme } 3 \\
\text { Education/training }\end{array}$ & $\begin{array}{c}\text { Theme } 4 \\
\text { Relationships }\end{array}$ \\
\hline Beecham et al. (2016) ${ }^{54}$ & $\sqrt{ }$ & & & $\sqrt{ }$ \\
\hline Beringer and Heckford (2012) ${ }^{60}$ & $\sqrt{ }$ & & $\sqrt{ }$ & $\sqrt{ }$ \\
\hline Billings and Holdsworth $(2013)^{55}$ & $\sqrt{ }$ & $\sqrt{ }$ & $\sqrt{ }$ & $\sqrt{ }$ \\
\hline Christenson et al. (2012) & $\sqrt{ }$ & $\sqrt{ }$ & & \\
\hline Dallas et al. $(2016)^{40}$ & $\sqrt{ }$ & $\sqrt{ }$ & & \\
\hline De Broca et al. (2016) $)^{41}$ & $\sqrt{ }$ & $\sqrt{ }$ & & $\sqrt{ }$ \\
\hline Durall, Zurakowski and Wolfe (2012) & & $\sqrt{ }$ & $\sqrt{ }$ & \\
\hline
\end{tabular}




\begin{tabular}{|c|c|c|c|c|}
\hline Freytag and Rauscher (2017) & & $\sqrt{ }$ & & $\sqrt{ }$ \\
\hline Garvie et al. (2012) & & $\sqrt{ }$ & & \\
\hline Heckford and Beringer (2014) & $\sqrt{ }$ & $\sqrt{ }$ & & \\
\hline Jacobs et al. (2015) & $\sqrt{ }$ & & $\sqrt{ }$ & \\
\hline Lotz et al. (2015) & $\sqrt{ }$ & & & \\
\hline Lotz et al. (2013) & $\sqrt{ }$ & & $\sqrt{ }$ & \\
\hline Lyon et al. (2017) & $\sqrt{ }$ & & & \\
\hline Lyon et al. (2014) & $\sqrt{ }$ & $\sqrt{ }$ & & \\
\hline Lyon et al. (2013) & $\sqrt{ }$ & $\sqrt{ }$ & & $\sqrt{ }$ \\
\hline Lyon et al. (2004) & $\sqrt{ }$ & $\sqrt{ }$ & & \\
\hline Lyon et al. (2009) & $\sqrt{ }$ & $\sqrt{ }$ & & $\sqrt{ }$ \\
\hline Sanders and Robinson (2017) & $\sqrt{ }$ & $\sqrt{ }$ & $\sqrt{ }$ & $\sqrt{ }$ \\
\hline Wiener et al. (2008) & $\sqrt{ }$ & $\sqrt{ }$ & & \\
\hline Wiener et al. (2012) & $\sqrt{ }$ & & & $\sqrt{ }$ \\
\hline Yotani, Kizawa and Shintaku (2017) & $\sqrt{ }$ & & & \\
\hline
\end{tabular}




\section{How ACP works in practice}

How ACP works in practice and how those involved in the process want it to work was the most commonly recurring theme across the 22 studies (see Table 3 ). Families want their child to be engaged in their own ACP and they want their child's opinion to be heard. ${ }^{40,44,53}$ However, participation is not always straightforward in practice. ACP can be characterised by disagreements between the family about the location of death ${ }^{58}$. This conflict can be compounded by a reluctance of HCPs and/or parents to engage in ACP if prognosis is poor 46,54 These issues can sometimes result in a breakdown in the relationships both within the family and between the family and HCPs.

Decisions within the ACP process are made more difficult by instability in the condition of young people. Parents generally desire care and treatment options to remain open, although decisions can be complicated by parents trying to visualise a hypothetical situation. ${ }^{54}$ Indeed, some evidence suggests that ACP might only be started after a crisis situation or when the health of the young people suddenly deteriorates. ${ }^{41,59}$ This means that although parents welcome ACP discussions, ${ }^{54}$ the timing of them often occurs too late for their children to be involved. Therefore, poor timing of ACP can explain why most decisions about the future of young people rarely involve the young people themselves, despite the willingness to engage them. ${ }^{54}$

There are also problems about the lack of information regarding available resources to help guide ACP discussions. ${ }^{58}$ These issues may create a barrier to the engagement 
of young people by impacting on their ability to make informed decisions about treatment, care or place of death. ${ }^{58}$ Specialist HCPs may also be more likely than other HCPs to both discuss ACP and identify barriers to the engagement of both young people and their family. ${ }^{51}$ Little research discussed the role of different HCPs and it is not possible to draw conclusions from the evidence. Nevertheless, it may be that a more specialist team, with experience of working with young people, can help to facilitate a more positive experience for those young people around ACP. ${ }^{55}$

Conversely, young people were reported to be more concerned with practical issues, such as the treatment they receive and anxiety for people who are left behind after their death. ${ }^{50}$ Yet although young people want to be involved in their own ACP, ${ }^{48}$ they are not always given the opportunity to participate. The resulting barriers identified above suggest that a poor approach to ACP can foster self-protective disengagement from young people due to worry, fear and anxiety such discussions can produce. ${ }^{57}$ This, in turn, results in a variety of documentation and patchy engagement of young people between different services. ${ }^{39,55}$ In contrast, a structured ACP intervention which is targeted on positive relationships and effective communication ${ }^{47,49}$ can facilitate young people's participation in their own ACP and contribute to the reduction of both stress and anxiety. ${ }^{48}$ Indeed, one study concluded that ACP could take place from the time of diagnosis. ${ }^{56}$ Such an approach can empower young people and facilitate their engagement in the ACP process regardless of perceived barriers. $48,56,57$

\section{Communication}


Poor, and the incorrect timing of, communication can cause unnecessary tension ${ }^{56}$ and be a barrier to young people's engagement in their ACP process ${ }^{44}$. However, there is potential to foster effective communication about ACP within families. ${ }^{43,50}$ The positive role of communication within the ACP process was highlighted by over a third of studies. ${ }^{40,42,45,47,49,50,52,58}$ Indeed, high-quality communication can help young people understand the care they need and develop skills to convey their wishes. ${ }^{40,48,49,51,52}$

ACP should be viewed as a process which recognises the shared vision and values of different generations within the same family. ${ }^{43}$ This approach may help to reduce death anxiety $^{43}$ and so facilitate the engagement of young people in their own ACP. HCPs should balance issues around hope for the future and respect for the individual with honest and meaningful conversations about dying. ${ }^{42,52,53,58}$ Open communication, as part of an age-appropriate and accessible communication style, can possibly facilitate the engagement of young people. 59

Despite their age, young people may be in the best position to discuss their own wishes, but communication can often be a barrier rather than a facilitator to their engagement in the ACP process. ${ }^{42,45,47}$ However, the reluctance, or discomfort, of HCPs to discuss EoL matters with young people can be a barrier to their engagement in their own decision-making process. ${ }^{59}$ This breakdown in communication too often can lead to a failure in relationships and also highlight inadequacies in training and education. ${ }^{42}$

\section{Training and education}


HCPs generally work at the desired pace of families and develop a flexible approach to engage them. ${ }^{55}$ Nevertheless, access to relevant training can enhance the quality of both communication and relationships of those in the ACP process. While education for young people can be key to raising awareness of ACP, ${ }^{57}$ access to and availability of training for HCPs was identified as a possible barrier to engaging young people in their own ACP. ${ }^{42,58}$ For example, HCPs are not always aware of relevant policies and can sometimes be unsure of their responsibilities. ${ }^{50}$ This can impact on their ability to engage young people in ACP discussions. ${ }^{42}$ Poor communication skills and a unwillingness to discuss ACP with young people have also been identified as potential training needs for HCPs in order to facilitate young people's engagement. ${ }^{59}$ Greater availability of training and guidance to support HCPs in the ACP process have started to address some of the issues identified above, ${ }^{60}$ but these need to be ongoing to have a lasting effect. ${ }^{55}$

Valuable strategies, such as surveys to stimulate conversations ${ }^{44}$ and the consideration of real-life situations, ${ }^{57}$ can facilitate sensitive communication at opportune times. These approaches can engage young people and facilitate open and honest discussions about their wishes, fears and hopes. Similarly, inter-disciplinary HCP discussions can also help to reduce professional tensions ${ }^{42}$ and so potentially facilitate the engagement of young people in their own ACP. However, current research indicates that this potential is not always being realised. ${ }^{42}$

\section{Relationships}

Assumptions about young people's understanding of ACP are sometimes based on their age. These beliefs can be a limiting factor to young people's engagement in their 
own ACP. ${ }^{43}$ Age may also contribute to tensions in relationships and discussions can sometimes be characterised by conflict because of the sensitive nature of the topic. ${ }^{39,49}$ A structured ACP process may help reduce this likelihood for tension by providing a framework in which to discuss wishes openly and intimately 48 and give friends and family members a clear role. ${ }^{43,57}$ Furthermore, positive relationships within families, within the multi-professional team, and between these groups can create a sense of trust between young people, their family and HCPs. ${ }^{53}$ Developing such relationships necessitates a multi-disciplinary approach to facilitate the engagement of young people in their own ACP and involve appropriate HCPs. ${ }^{41}$ In these situations, peer support for HCPs can enrich professional relationships ${ }^{60}$ and so complement the role of the family in ACP. 43

Building trusting relationships is also important in the ACP process. ${ }^{54}$ Evidence stresses that quality relationships, which are based on mutual understanding, trust, and respect, can help recognise the wishes of each person as valuable within ACP. ${ }^{41,43}$ Successful relationships also depend on developing effective communication and accessing relevant training $42,48,50$ In short, constructive, encouraging and progressive relationships can allow ACP to flourish and facilitate the engagement of young people in their own ACP; negative, pessimistic and difficult relationships can be more of a barrier to their engagement.

\section{Discussion}

\section{Main findings}

Most studies conducted within hospitals and specialist centres identified communication as one of the main factors impacting on the success of engaging young 
people in their ACP process. ${ }^{40,42,48-50,52,56,58}$ Communication, which is clear, timely, and language which is both age- and developmentally-focused, can facilitate the engagement of young people by helping them understand, and convey, the care they want at the end-of-life. ${ }^{40,48,49,51,52}$ This approach allows openness and honesty in all relationships in the ACP process and helps family members share wishes and values for the future. ${ }^{43}$ Conversely, communication can often be a barrier to ACP when these issues are not recognised 44,56 and this can negatively impact the engagement of young people.

Five studies ${ }^{43,48,49,53,57}$ established that effective relationships, characterised by this openness and honesty, as well as age-appropriate language and communication style, were central to successfully engaging young people in their ACP. Evidence also recognised $\mathrm{ACP}$ is a complex process, and the availability of training for HCPs is crucial to both help understand these complexities and overcome potential barriers. ${ }^{57}$

Additionally, training to enhance HCPs' knowledge and understanding of relevant policies and legislation, and specifically communication training, would facilitate the introduction and engagement of young people in their ACP process. ${ }^{42,58}$ Such training can help raise awareness of $\mathrm{ACP}^{57}$ and highlight the role of $\mathrm{HCPs}$ in engaging young people in ACP discussions. ${ }^{42}$ Access to training can therefore be understood as a potential facilitator to introduce conversations about ACP, ease worries and concerns of those involved in the process and engage young people to help them communicate their EoL wishes. ${ }^{61}$ Currently there is little evidence to show that this training for HCPs is consistent. ${ }^{55,62}$ Consequently, availability and access to such training may act as more of a barrier to engaging young people in their own ACP. 60 Therefore, the 
combined impact of strained relationships, poor communication, and restricted availability of training for HCPs presents a mixed picture of barriers ACPfYP.

Despite the barriers identified, there were also encouraging signs where young people had been engaged. For example, the alignment of practice and policy, whereby HCPs feel guidance is provided to facilitate the engagement of young people and start difficult conversations, can help young people develop skills to convey their own care treatment decisions ${ }^{52,53}$ and develop their resilience ${ }^{40}$. A collaborative approach to ACPfYP would further increase the potential for compassionate and self-directed care, comfort and support both before and after death. ${ }^{53}$

\section{Limitations}

There are several limitations to this review. A narrative synthesis is aimed at, and supports, the combination of heterogeneous studies, but the varied nature of the studies can make it difficult to synthesise the information. Therefore, a potential for bias by over-representing one or more studies, or themes, remains a possibility. Variety in key terms and definitions in the literature used to refer to ACPFYP made searching for articles and discussing the engagement of young people in the process a challenging task. The relatively small amount of available literature also made the review additionally complicated. For example, some studies focused on parents' or HCPs' perception of the engagement of young people rather than focusing on the views of the young people themselves. Indeed, no study focused on the views and experiences of the young people within the ACP process from their own perspective. Responses from different groups within the ACP process were also sometimes combined, which made it hard to differentiate individual viewpoints. Furthermore, 
some studies included in the review form a 'study cluster', where a group of studies originate from a single institution or publication. ${ }^{63}$ This approach provides depth of understanding for the context and implementation of ACP and has been balanced with other findings in this review. ${ }^{63}$ This depth is particularly important when researching complex interventions and establishing their effectiveness. ${ }^{63}$ However, there may also be limitations in providing a full breadth of understanding around ACPfYP.63 Additionally, each study has been individually assessed and only those studies which met the criteria for this synthesis have been included. As a result, previous publications they referred to have not been included if they do not meet the criteria, even if they include relevant methodological guidelines. This is an inherent limitation of qualitative assessment frameworks and represents a potential bias in the scoring of included studies. Furthermore, $\mathrm{BH}$ completed the scoring of the studies independently and disagreements were discussed within the research team (MoB,AF and KK). This process provided transparency and rigour but also may have created potential bias in the scoring of included studies.

While qualitative methods may be better suited to answering questions of perception, such approaches also have limitations. A key factor of the studies included in this review is the limited focus of some of the research. Nearly a quarter of studies $^{41,50,54,56,57}$ were limited to a single institution where data saturation may not be achievable. Nevertheless, the qualitative studies included in the review were useful to address the research question and their results are helpful to understand reported practice. 
Furthermore, studies inevitably vary in quality. Factors which negatively impacted on the quality of research included: a lack of clarity in their aim(s); ${ }^{41,52,55}$ a poor description of data collection and sampling methods; ${ }^{52,54}$ incomplete data analysis; ${ }^{24,39,41,50,52,53}$ poor consideration of ethical issues; $24,39,41-43,50,52,54,58$ or a lack of generalisability and/or discussion of implications for policy and practice. ${ }^{41,51,52,58}$ Nevertheless, only a minority of papers $(n=4)^{24,41,52,58}$ were judged either as poor or very poor in overall quality. Although this review identifies available literature, existing research is not necessarily representative of the current engagement of young people in their ACP. Consequently, more research is needed in this area. Research is also needed to investigate the experience and involvement of all participants (young people, their family and HCPs) in the ACP process.

\section{Strengths}

Despite the limitations above, the included studies and synthesis approach satisfactorily answer the review question. The synthesis was conducted primarily by one reviewer but the procedure was checked at each stage by the research team. This process reduced the potential for bias and ensured the review was conducted rigourously and is replicable. Utilising an identifiable and tested approach to the synthesis further strengthened the reliability of the results. The rigour of the literature search resulted in the comprehensive identification of relevant studies. Inclusion of all applicable studies in the synthesis allowed for a broad and full understanding of the phenomenon under review. Even with the heterogeneous nature of the studies, the findings appear similar. Most of the studies were conducted in the United States and/or in hospitals/other institutions but the overall congruence between studies gives 
encouragement regarding the strength of the findings and their applicability to a variety of settings.

\section{What this study adds}

This review presents an initial picture of young people's engagement in their own ACP. As part of this, the review has identified barriers and facilitators to the engagement of young people in the complexity of their own ACP discussions. These aspects include communication, relationships and training available to healthcare professionals. These factors influence how ACP works in practice and help determine the success or failure to engage young people in the process. As far as it is known, this is the first review of its kind and highlights the importance of understanding the complex factors in ACP. The implications of these findings demonstrate consequences for practice by considering the components of the process which can either help to engage or hinder young people from participating. The conclusions can also influence policy by informing areas such as communication training and stressing the importance of multidisciplinary teams when engaging and supporting young people's engagement in their ACP. These areas are particularly relevant for UK policy and practice because ACP documentation is not standardised and there is an unclear picture of how young people can be engaged in discussions about their care. Guidelines can be developed to recognise potential barriers and so facilitate the engagement of young people.

As a result of this review, there are several areas where future research could be conducted. The opinions and experiences of young people are not included in the current review and so the extent to which young people are able to engage in their own ACP should be explored from their own viewpoint. Similarly, there is a lack of existing 
qualitative research which explores barriers and facilitators to engaging young people in their own ACP. Current research explores the engagement of young people from one or two perspectives within the process of ACP. Research is now needed to explore all groups concurrently in the ACP process: young people, their parents/carers and healthcare professionals. The role of other professionals, such as those in mental health, psychologists and case workers, also needs to be investigated. This focus will provide additional quality research to adequately meet existing gaps in knowledge.

\section{Conclusion}

With reference to the aim of this review, there can be a variety of people involved in the process of ACPfYP: parents/carers, different HCPs and, sometimes, young people themselves. The engagement of young people in their own ACP seems to be something desired by all participants involved in ACPfYP. However, this engagement appears to be inconsistent in practice. The congruence of policy and the aims of ACP are necessary to facilitate this engagement but too often, these factors do not work together effectively.

There are also various potential barriers to young people's engagement in their ACP, such as poor communication, conflict within relationships of those involved in the process and variable access to training for HCPs. Conversely, these factors can also be facilitators to engaging young people when their importance is recognised and time and resources are invested into their effective use. Specialist HCPs may be in the best position to identify these factors and take advantage of them ${ }^{51}$, but more research is needed to confirm this. 
Consequently, there is no general agreement of when it is best to introduce ACP discussions. Only two studies identified an optimal time to start ACP and both agreed that it is best introduced at diagnosis. ${ }^{33}$ With no further investigation of the timing of $\mathrm{ACP}$, this represents a gap in current knowledge.

\section{Authorship}

The review was written primarily by $\mathrm{BH}$, with contributions from the rest of the research team (MoB,AF and KK). All authors have:

(i) Made a substantial contribution to the concept or design of the work; or acquisition, analysis or interpretation of data,

(ii) Drafted the article or revised it critically for important intellectual content,

(iii) Approved the version to be published,

(iv) Have participated sufficiently in the work to take public responsibility for appropriate portions of the review.

\section{Declaration of conflicting interests}

The author(s) declared no potential conflicts of interest with respect to the research, authorship and/or publication of this article.

\section{Research ethics and patient consent}

No ethics/research governance/data protection approvals were necessary to conduct this review. 


\section{Funding}

The lead author is currently undertaking a PhD in Health, which is funded by Edge Hill

University. No separate financial support was received for the research, authorship and/or publication of this article.

\section{References}

1. Hawker S, Payne S, Kerr C, et al. Appraising the evidence: reviewing disparate data systematically. Qual Health Res 2002; 12: 1284-1299.

2. National Gold Standards Framework Centre. Welcome to the Gold Standards Framework. The Gold Standards Frameworkhttp://www.goldstandardsframework.org.uk/ (2017, accessed 12 September 2017).

3. Seymour J, Almack K, Kennedy S. Implementing advance care planning: a qualitative study of community nurses' views and experiences. BMC Palliat 
Care 2010; 9: 4.

4. Reynolds J, Croft S. How to implement the Gold Standards Framework to ensure continuity of care. Nurs Times 2010; 106: 10-13.

5. Lund S, Richardson A, May C. Barriers to advance care planning at the end of life: An explanatory systematic review of implementation studies. PLoS One 2015; 10: 1-15.

6. Hayhoe B, Howe A, Gillick M, et al. Advance care planning under the Mental Capacity Act 2005 in primary care. Br J Gen Pract 2011; 61: e537-41.

7. Montreuil M, Carnevale FA. A concept analysis of children's agency within the health literature. J Child Heal Care 2015; 1-9.

8. DH. Better Care: Better Lives Improving outcomes and experiences for children, young people and their families living with life limiting and life threatening conditions. Bristol, 2008.

9. $\quad$ Nursing Times. What is the Liverpool Care Pathway? Nursing

Timeshttps://www.nursingtimes.net/clinical-subjects/end-of-life-and-palliativecare/what-is-the-liverpool-care-pathway/5051586.article (2012, accessed 23 November 2016).

10. Linda Emanuel, Michael Barry, John Stoeckle LE and E. Advance Directives for Medical Care - A Case for Greater Use. N Engl J Med 1991; 324: 889-895.

11. Hynson J. Palliative care for children. J Consum Heal Forum Aust 2009; March: 22-23.

12. Mitchell S, Dale J. Advance Care Planning in palliative care: A qualitative investigation into the perspective of Paediatric Intensive Care Unit staff. Palliat Med 2015; 29: 371-379.

13. TfSL. Why we are here.

14. Russell S. Advance care planning: whose agenda is it anyway? Palliat Med 2014; 28: 997-9.

15. Sudore RL, Lum HD, You JJ, et al. Defining Advance Care Planning for Adults: A Consensus Definition From a Multidisciplinary Delphi Panel. J Pain Symptom Manage 2017; 53: 821-832.

16. South Central NHS Trust. Guide to using the Child and Young Person's Advance Care Plan.

17. West Midlands Paediatric Palliative Care Network NHS. Child and Young Person's Advance Care Plan:

Policy.https://www.togetherforshortlives.org.uk/assets/0000/1485/6b_ACP_Poli cy_2012.pdf (2011).

18. TfSL. Family Factsheets: Care Planning in Advance.

19. Horridge K. Advance Care Planning: practicalities, legalities, complexities and controversies. Arch Dis Child 2015; 100: 380-385.

20. Cass $\mathrm{H}$. National priorities and crystal ball gazing. In: A Palliative Care Journey: National Paediatric and Neonatal Palliative Care Conference. 2016, pp. 1-60.

21. Bell CJ. Understanding Quality of Life in Adolescents living with Advanced Cancer. J Chem Inf Mode/2013; 53: 1689-1699.

22. Bergstraesser E, Zimmermann K, Eskola K, et al. Paediatric end-of-life care needs in Switzerland: current practices, and perspectives from parents and professionals. A study protocol. J Adv Nurs 2015; 71: 1940-1947.

23. NHS South East Coast Clinical Senate. Improving Advance Care Planning in Kent, Surrey and Sussex. 2014.

24. Heckford E, Beringer AJ. Advance Care Planning: Challenges and Approaches 
for Pediatricians. J Palliat Med 2014; 17: 1049-1053.

25. Mitchell S, Plunkett A, Dale J. Use of formal advance care planning documents: a national survey of UK Paediatric Intensive Care Units. Arch Dis Child 2014; 99: 327-30.

26. Snilstveit B, Oliver S, Vojtkova M. Narrative approaches to systematic review and synthesis of evidence for international development policy and practice. $J$ Dev Eff 2012; 4: 409-429.

27. Firn J, Preston N, Walshe C. What are the views of hospital-based generalist palliative care professionals on what facilitates or hinders collaboration with inpatient specialist palliative care teams? A systematically constructed narrative synthesis. Palliat Med 2016; 30: 240-256.

28. Gowing A, Robinson L. Advance care planning. InnovAiT Educ Inspir Gen Pract 2014; 7: 363-369.

29. TfSL. Children's palliative care definitions.http://www.togetherforshortlives.org.uk/assets/0000/1638/CPC_defi nitions.pdf (2013, accessed 23 October 2015).

30. World Health Organisation. Definition and list of health professionals. Transformative Education for Health

Professiona/shttp://whoeducationguidelines.org/content/1-definition-and-listhealth-professionals (2015, accessed 13 December 2015).

31. TfSL. A Core Care Pathway for Children with Life-limiting and Life-threatening Conditions. Bristol, 2013.

32. Neuberger J, Aaronovitch D, Bonser T, et al. More Care Less Pathway: A Review of the Liverpool Care Pathway. 2013.

33. TfSL. Life-limiting and life-threatening conditions in children and young people in the United Kingdom; national and regional prevalence in relation to socioeconomic status and ethnicity. Epidemiology 2011; 1-129.

34. US National Library of Medicine. MeSH Browser. Mesh Descriptor Datahttps://meshb.nlm.nih.gov/record/ui?ui=D055815 (2017, accessed 6 April 2017).

35. Liberati A, Altman DG, Tetzlaff J, et al. The PRISMA statement for reporting systematic reviews and meta-analyses of studies that evaluate health care interventions: Explanation and elaboration. PLoS Med, 6. Epub ahead of print 2009. DOI: 10.1371/journal.pmed.1000100.

36. Stewart LA, Clarke M, Rovers M, et al. Preferred Reporting Items for a Systematic Review and Meta-analysis of Individual Participant Data. Jama 2015; 313: 1657-1665.

37. Popay J, Roberts H, Sowden A, et al. Guidance on the Conduct of Narrative Synthesis in Systematic Reviews. A Prod from ESRC Methods Program. Epub ahead of print 2006. DOI: 10.1111/j.1523-536x.1995tb00261.x.

38. Robinson L, Dickinson C, Rousseau N, et al. A systematic review of the effectiveness of advance care planning interventions for people with cognitive impairment and dementia. Age Ageing 2012; 41: 263-269.

39. Beringer AJ, Heckford EJ. Was there a plan? End-of-life care for children with life-limiting conditions: a review of multi-service healthcare records. Child Care Health Dev 2014; 40: 176-183.

40. Dallas $\mathrm{RH}$, Kimmel A, Wilkins ML, et al. Acceptability of Family-Centered Advanced Care Planning for Adolescents With HIV. Pediatrics 2016; 138: e20161854-e20161854.

41. de Broca A, Lutun A, Gourmel A, et al. Advance care planning and place of 
death in a paediatric palliative care unit in France. Eur J Palliat Care 2016; 23: 16-18.

42. Durall A, Zurakowski D, Wolfe J. Barriers to Conducting Advance Care Discussions for Children With Life-Threatening Conditions. Pediatrics 2012; Apr 129: e975-e982.

43. Freytag J, Rauscher EA. The Importance of Intergenerational Communication in Advance Care Planning: Generational Relationships among Perceptions and Beliefs. J Health Commun 2017; 22: 488-496.

44. Garvie PA, He J, Wang J, et al. An exploratory survey of end-of-life attitudes, beliefs, and experiences of adolescents with HIVIAIDS and their families. $J$ Pain Symptom Manage 2012; 44: 373-385.e29.

45. Lyon ME, Jacobs S, Briggs L, et al. Family-Centered Advance Care Planning for Teens With Cancer. JAMA Pediatr 2013; 167: 460.

46. Lotz JD, Jox RJ, Borasio GD, et al. Pediatric Advance Care Planning: A Systematic Review. Pediatrics 2013; 131: e873-e880.

47. Lyon ME, D'Angelo LJ, Dallas $\mathrm{RH}$, et al. A randomized clinical trial of adolescents with HIVIAIDS: pediatric advance care planning. AIDS Care Psychol Socio-Medical Asp AIDS/HIV 2017; 29: 1287-1296.

48. Lyon ME, Jacobs S, Briggs L, et al. A Longitudinal, Randomized, Controlled Trial of Advance Care Planning for Teens With Cancer: Anxiety, Depression, Quality of Life, Advance Directives, Spirituality. J Adolesc Heal 2014; 54: 710717.

49. Lyon ME, Garvie PA, Briggs L, et al. Development, feasibility and acceptibility of the Family/Adolescent-Centred (FACE) Advance Care Planning Intervention for Adolescents with HIV. J Palliat Med 2009; 12: 363-372.

50. Wiener L, Ballard E, Brennan T, et al. How I Wish to be Remembered: The Use of an Advance Care Planning Document in Adolescent and Young Adult Populations. J Palliat Med2008; 11: 1309-1313.

51. Yotani N, Kizawa Y, Shintaku H. Differences between Pediatricians and Internists in Advance Care Planning for Adolescents with Cancer. J Pediatr 2017; 182: 356-362.

52. Christenson K, Lybrand SA, Hubbard CR, et al. Including the Perspective of the Adolescent in Palliative Care Preferences. J Pediatr Heal Care 2010; 24: 286-291.

53. Wiener $\mathrm{L}$, Zadeh $\mathrm{S}$, Battles $\mathrm{H}$, et al. Allowing adolescents and young adults to plan their end-of-life care. Paediatrics 2012; 130: 897-905.

54. Beecham E, Oostendorp L, Crocker J, et al. Keeping all options open: Parents' approaches to advance care planning. Heal Expect 2016; 1-10.

55. Billings J, Holdsworth L. Service Evaluation of an Advance Care Plan Tool.http://www.kent.ac.uk/chss/docs/advance-care-plan-tool-report.pdf (2013).

56. Lyon ME, McCabe MA, Patel KM, et al. What do adolescents want? An exploratory study regarding end-of-life decision-making. J Adolesc Heal 2004; 35: 529.e1-529.e6.

57. Sanders S, Robinson EL. Engaging College Undergraduates in Advance Care Planning. OMEGA - J Death Dying 2017; 74: 329-344.

58. Jacobs S, Perez J, Cheng YI, et al. Adolescent End of Life Preferences and Congruence With Their Parents' Preferences: Results of a Survey of Adolescents With Cancer. Pediatr Blood Cancer 2015; 62: 710-714.

59. Lotz JD, Jox RJ, Borasio GD, et al. Pediatric advance care planning from the 
perspective of health care professionals: A qualitative interview study. Palliat Med 2015; 29: 212-222.

60. Beringer AJ, Heckford EJ. Was there a plan? End-of-life care for children with life-limiting conditions: A review of multi-service healthcare records. Child Care Health Dev 2012; 40: 176-183.

61. Durall A, Zurakowski D, Wolfe J. Barriers to Conducting Advance Care Discussions for Children With Life-Threatening Conditions. Pediatrics 2012; Apr 129: e975--e982.

62. Lyon ME, Williams PL, Woods ER, et al. Do-Not-Resuscitate Orders and/or Hospice Care, Psychological Health, and Quality of Life among Children/Adolescents with Acquired Immune Deficiency Syndrome. J Palliat Med 2008; 11: 459-469.

63. Booth A, Harris J, Croot E, et al. Towards a methodology for cluster searching to provide conceptual and contextual 'richness' for systematic reviews of complex interventions: case study (CLUSTER). BMC Med Res Methodol2013; 13: 118.

\section{Appendix 1 - Assessment framework ${ }^{1}$}

Author and title:

Date:

\begin{tabular}{|l|l|l|l|l|l|}
\hline & Good & Fair & Poor & $\begin{array}{l}\text { Very } \\
\text { poor }\end{array}$ & Comment \\
\hline 1. Abstract and title & & & & & \\
\hline 2. Introduction and aims & & & & & \\
\hline 3. Method and data & & & & & \\
\hline 4. Sampling & & & & & \\
\hline 5. Data analysis & & & & & \\
\hline 6. Ethics and bias & & & & & \\
\hline 7. Findings/results & & & & & \\
\hline
\end{tabular}


8. Transferability/generalisability

9. Implications

\section{Total}

\section{Appendix 2 - Assessment framework ${ }^{1}$}

1. Abstract and title: Did they provide a clear description of the study?

Good Structured abstract with full information and clear title

Fair Abstract with most of the information

Poor Inadequate abstract

Very poor No abstract

2. Introduction and aims: Was there a good background and clear statement of the aims of the research?

Good Full but concise background to discussion/study containing up-to- date literature review and highlighting gaps in knowledge

Clear statement of aim AND objectives including research questions

Fair Some background and literature review

Research questions outlined

Poor Some background but no aim/objectives/questions, OR Aims/objectives but inadequate background

Very poor No mention of aims/objectives

No background or literature review

3. Method and data: Is the method appropriate and clearly explained?

Good Method is appropriate and described clearly (e.g., questionnaires included) Clear details of the data collection and recording

Fair Method appropriate, description could be better

Data described

Poor Questionable whether method is appropriate Method described inadequately

Little description of data

Very poor No mention of method AND/OR Method inappropriate AND/OR

No details of data.

4. Sampling: Was the sampling strategy appropriate to address the aims?

Good 


\begin{tabular}{|ll} 
& $\begin{array}{l}\text { Details (age/gender/race/context) of who was studied and how they were } \\
\text { recruited } \\
\text { Why this group was targeted }\end{array}$ \\
Fair & $\begin{array}{l}\text { The sample size was justified for the study } \\
\text { Response rates shown and explained }\end{array}$ \\
Poor & $\begin{array}{l}\text { Sample size justified } \\
\text { Very poor }\end{array}$ \\
& $\begin{array}{l}\text { Most information given, but some missing } \\
\text { Sampling mentioned but few descriptive details } \\
\text { No details of sample }\end{array}$ \\
\hline
\end{tabular}

5. Data analysis: Was the description of the data analysis sufficiently rigorous?

Good Clear description of how analysis was done

Qualitative studies: Description of how themes derived/respondent validation or triangulation

Quantitative studies: Reasons for tests selected hypothesis driven/numbers add up/statistical significance discussed

Fair Qualitative: Descriptive discussion of analysis.

Quantitative

Poor Minimal details about analysis

Very poor No discussion of analysis

6. Ethics and bias: Have ethical issues been addressed, and what has necessary ethical approval gained? Has the relationship between researchers and participants been adequately considered?

Good Ethics: Where necessary issues of confidentiality, sensitivity, and consent were addressed

Fair Bias: Researcher was reflexive and/or aware of own bias

Poor Lip service was paid to above (i.e., these issues were acknowledged)

Very poor Brief mention of issues No mention of issues

7. Results: Is there a clear statement of the findings?

Good Findings explicit, easy to understand, and in logical progression

Tables, if present, are explained in text

Results relate directly to aims

Sufficient data are presented to support findings

Fair $\quad$ Findings mentioned but more explanation could be given

Data presented relate directly to results

Poor Findings presented haphazardly, not explained, and do not progress logically

Very poor from results

Findings not mentioned or do not relate to aim

8. Transferability or generalizability: Are the findings of this study transferable (generalizable) to a wider population? 
Good Context and setting of the study is described sufficiently to allow comparison with other contexts and settings, plus high score in Question 4 (sampling)

Fair Some context and setting described, but more needed to replicate or compare the study with others, PLUS fair score or higher in Question 4

Poor Minimal description of context/setting

Very poor No description of context/setting

9. Implications and usefulness: How important are these findings to policy and practice?

Good Contributes something new and/or different in terms of understanding/insight or perspective

Suggests ideas for further research

Suggests implications for policy and/or practice

Fair Two of the above (state what is missing in comments)

Poor Only one of the above

Very poor None of the above 